Published in final edited form as:

Cardiol Clin. 2016 August ; 34(3): 451-472. doi:10.1016/j.ccl.2016.04.005.

\title{
PULMONARY HYPERTENSION IN CHILDREN
}

\author{
Dunbar Ivy, MD \\ University of Colorado School of Medicine, Children's Hospital Colorado, 13123 East $16^{\text {th }}$ Ave, \\ B100, Aurora, CO 80045, dunbar.ivy@childrenscolorado.org
}

\section{Introduction}

Untreated, pulmonary arterial hypertension (PAH) in children carries a particularly poor prognosis. In the NIH registry, the median untreated survival for children after diagnosis of idiopathic PAH (IPAH) was reported to be 10 months as opposed to 2.8 years for adults. ${ }^{1}$ In 1999, further studies by Barst et al showed that survival for children with IPAH who were candidates for intravenous prostacyclin but were unable to be treated with this therapy was poor with a survival of $45 \%$ and $29 \%$ respectively at 1 and 4 years. ${ }^{2}$ Recent advances in the understanding of the pathobiology of idiopathic pulmonary arterial hypertension and new treatment therapies have resulted in marked improvement in the prognosis for children with PAH (Figure 1) ${ }^{3,4}$ Similarities and differences persist in comparison of children and adults with PAH. ${ }^{5}$ In both groups, disease progression is rapid, perhaps more rapid in children than in adults, and left untreated elevation of pulmonary arterial pressure and resistance leads to right ventricular failure, clinical deterioration and death. In contrast, many aspects of pulmonary vascular disease of children are distinct from adult pulmonary hypertension. Pediatric pulmonary hypertension is intrinsically linked to lung growth and development in the younger child (Figure 2). ${ }^{6}$ The onset of pulmonary vascular injury in the younger child may allow the possibility of greater reversal of pulmonary vascular disease, particularly in bronchopulmonary dysplasia (BPD) and other lung diseases of childhood. Medical management of children follows a similar algorithm to that of adults treated with idiopathic pulmonary vascular disease. ${ }^{4,7,8}$ The resurgence of the Potts shunt, originally used to increase pulmonary blood flow in congenital heart disease (CHD) in the 1950s, has allowed for a surgical right-to-left shunt in the younger child failing medical management with end stage disease. ${ }^{9}$

\section{Definition}

Similar to adults, pulmonary arterial hypertension is defined as a mean pulmonary arterial pressure greater than $25 \mathrm{mmHg}$ at rest, with a normal pulmonary artery wedge pressure less than $15 \mathrm{mmHg}$ and an increased pulmonary vascular resistance greater than 3 Wood units $\times$ $\mathrm{M}^{2}{ }^{4,10}$ The Nice classification is appropriate for adults and children. ${ }^{4,11}$ In younger children, the pulmonary arterial pressure is frequently referenced as a ratio to systemic

Publisher's Disclaimer: This is a PDF file of an unedited manuscript that has been accepted for publication. As a service to our customers we are providing this early version of the manuscript. The manuscript will undergo copyediting, typesetting, and review of the resulting proof before it is published in its final citable form. Please note that during the production process errors may be discovered which could affect the content, and all legal disclaimers that apply to the journal pertain. 
arterial pressure with a significant difference being greater than 0.5 . Pulmonary hypertensive vascular disease complicates the course of certain forms of single ventricle heart disease in which mean PAP is less than $25 \mathrm{mmHg}$ but pulmonary vascular resistance (PVR) is high leading to failure of the circulation. ${ }^{6} \mathrm{PAH}$ associated with congenital heart disease is heterogeneous, and ranges from classic Eisenmenger syndrome with reversal of a central shunt and cyanosis to IPAH-like CHD with coincidental defects (Box 1). ${ }^{11}$

\section{Epidemiology}

National registries from the United Kingdom, the Netherlands, and Spain have all shown a lower incidence for IPAH in children compared to adults. The incidence of IPAH in the national registry from the United Kingdom was 0.48 cases per million children per year and the prevalence was 2.1 cases per million. ${ }^{12}$ In the Netherlands, annual incidence and point prevalence averaged 0.7 and 2.2 cases per million children, respectively (Figure 3). ${ }^{13}$ Likewise, in the Spanish registry the incidence and prevalence were 0.49 and 2.9 cases per million children. ${ }^{14} \mathrm{PAH}$ associated with CHD represents highly heterogeneous subgroups. Transient PAH is seen in children with CHD and systemic-to-pulmonary shunt, in who PAH resolves after early shunt correction. However, in a small subset of CHD progressive PAH after surgical repair (APAH-CHD Group D, Box 1) has a particularly poor diagnosis (Figure 4). ${ }^{15}$ APAH-CHD occurs more frequently in children than adults with an incidence and prevalence 2.2 and 15.6 cases per million children. Syndromes are frequently present in progressive PAH. Recent national database studies have suggested an increasing prevalence of hospitalized children with $\mathrm{PH}$ as a co-morbidity. ${ }^{16,17}$

\section{Highlighted Causes of PH}

\section{Heritable PAH}

Bone morphogenetic protein receptor type 2 (BMPR2) mutations have been identified in children and adults with idiopathic pulmonary arterial hypertension and familial PAH $^{18-24}$. The pattern of inheritance in children with BMPR2 mutations is the same as adults with an autosomal dominant pattern with reduced penetrance. BMPR 2 mutations have been evaluated in several pediatric series with inconsistent results. Grunig found no BMPR2 mutations or deletions in 13 children with IPAH. ${ }^{24}$ However, in a study by Harrison et al, $22 \%$ of children with idiopathic pulmonary arterial hypertension or pulmonary hypertension associated with congenital heart disease had activin-like kinase type-1 $(A L K-1)$ or $B M P R 2$ mutations. ${ }^{21}$ In a Japanese study children with severe HPAH were as likely to have a BMPR2 mutation as an ALK-1 mutation. ${ }^{25}$ Advanced gene-sequencing methods have facilitated the discovery of additional genes with mutations among those with and those without familial forms of PAH (SMAD-9, CAV1, KCNK3, EIF2AK4, TBX4). ${ }^{18,26-28}$

\section{Single Ventricle Circulation}

Pulmonary vascular resistance plays a key role in the outcome of the single ventricle patient. In the patient with single ventricle physiology, such as hypoplastic left heart syndrome, flow to the pulmonary circulation is without a pumping chamber and relies on several factors to be successful: unobstructed pulmonary blood flow and venous drainage, low PAP and PVR, 
low ventricular end diastolic pressure, and adequate systolic single ventricular function. Low PAP and PVR is required for a successful Fontan surgery as well as a favorable long-term outcome. ${ }^{29}$ Increases in pulmonary artery pressure and PVR lead to abnormalities of the systemic and pulmonary circulations. High PVR leads to low cardiac output and is associated with Fontan failure as well as complications such as protein losing enteropathy ${ }^{30}$ and plastic bronchitis. ${ }^{31}$ Risk factors for palliation failure include mean PAP $>15 \mathrm{~mm} \mathrm{Hg}$, TPG $>8 \mathrm{~mm} \mathrm{Hg}$, and PVRI $>2.5$ Wood $\mathrm{U} \times \mathrm{m}$ (Figure 13). ${ }^{32}$ Pulmonary vascular disease with muscular thickening of the pulmonary arteries and an overexpression of NO synthase has been found in patients with a failing Fontan circulation. ${ }^{33}$ Likewise, children receiving a heart transplant for Fontan failure have an elevated PVR one year after transplantation. ${ }^{34}$

Based on the above observations, treatment of the Fontan patient with pulmonary vasodilator therapy in small series has been shown to improve hemodynamics and saturation, exercise capacity and treat complications such as protein losing enteropathy and plastic bronchitis in the "failing" and "non-failing Fontan patient. ${ }^{35-37}$ The vasoconstrictor peptide endothelin-1 is increased in Fontan patients. ${ }^{38}$ Several studies have suggested an exercise benefit with endothelin receptor antagonists. ${ }^{39-41}$

\section{Bronchopulmonary Dysplasia}

Bronchopulmonary dysplasia (BPD) is the chronic lung disease associated with prematurity, and is one of the many developmental lung diseases of childhood associated with PH (Box 2). Advances in neonatal care have improved survival of extremely premature infants but morbidity from BPD is significant, and PH is diagnosed in up to $20 \%$ of preterm babies. ${ }^{42}$ $\mathrm{PH}$ is associated with mild, moderate and severe BPD, with increasing PH associated with worse BPD (Figure 5). PH is usually diagnosed by echocardiogram, but the variable rates of $\mathrm{PH}$ diagnosis are likely related to lack of consistent echocardiographic criteria. However, early echocardiographic signs of pulmonary vascular disease as early as 7 days of life (ventricular septal wall flattening and right ventricle dilation) are associated with higher risk of late $\mathrm{PH}$ in preterm infants at risk of BPD. ${ }^{43} \mathrm{PH}$ is thought to result from increased vascular tone, hypertensive remodeling and a limited vascular bed. Risk factors for $\mathrm{PH}$ include lower gestational age, small-for-gestational age birth weight, oligohydramnios, preeclampsia, prolonged duration of mechanical ventilation and oxygen therapy, which may suggest genetic, epigenetic or environmental factors. ${ }^{42-45} \mathrm{PH}$ can resolve in some premature infants, persistence and severity of $\mathrm{PH}$ is associated with significant mortality. One recent study showed a $53 \%+/-11 \%$ survival 2 years after diagnosis of $\mathrm{PH}^{46}$

\section{Evaluation}

Recent guidelines on the diagnosis and management of children with PH have filled gaps in evaluation and treatment of children with $\mathrm{PH}^{44} \mathrm{~A}$ complete evaluation for all possible causes of PAH is required before the diagnosis of IPAH is made (Box 3). Certain diseases, such as connective tissue disease or chronic thromboembolic pulmonary hypertension, are less likely to be discovered in children, but still should be excluded. As discussed below, cardiac catheterization is required to rule out subtle congenital heart disease, such as pulmonary vein disease, to determine right atrial pressure, pulmonary arterial pressure, 
pulmonary vascular resistance, and to determine vasoreactivity to acute vasodilator testing. ${ }^{47}$ Lung biopsy is rarely performed but may be helpful to exclude certain diseases, such as pulmonary veno-occlusive disease, pulmonary capillary hemangiomatosis or alveolar capillary dysplasia. Furthermore, in certain forms of interstitial lung disease, such as pulmonary capillaritis or hypersensitivity pneumonitis, lung biopsy may be beneficial as treatment of these disorders varies markedly from the approach used in IPAH.

Echocardiography is a very useful non-invasive screening tool to evaluate patients with a clinical suspicion of PAH. ${ }^{48}$ The echocardiogram documents cardiac anatomy, right ventricular size and function, left ventricular systolic and diastolic function, morphology and function of valves, and the presence of pericardial effusion or a patent foramen ovale. Doppler ultrasound can be used noninvasively to estimate the pulmonary artery systolic pressure and to suggest the presence of increased pulmonary vascular resistance. A qualitative assessment of RV function is also important. This is often challenging due to the geometry of the RV. Several measures are available to attempt to quantify the degree of RV dysfunction including the Tei index, (myocardial performance index), RV ejection fraction, RV fractional area change and the tricuspid annular plane systolic excursion (TAPSE). ${ }^{49-56}$ Normal values for TAPSE in children have recently been published and should serve as a reference for children with PH (Figure 6).$^{52}$. The ratio of right ventricle to left ventricle size at end systole is a strong predictor of outcome (Figure 7). ${ }^{57}$ An increasing RV/LV systolic ratio is associated with an increasing hazard for a clinical event (hazard ratio, 2.49; 95\% confidence interval, 1.92-3.24). Pulmonic valve insufficiency is frequently seen, and characteristics of the pulmonic regurgitant flow velocity or changes in the systolic flow velocity profile across the pulmonic valve also can be used to estimate noninvasively the pulmonary artery diastolic pressure and the mean pulmonary artery pressure. ${ }^{58}$ The presence of a pericardial effusion is rare in children, but when present, suggests a poor prognosis. ${ }^{53,59}$ As PH progresses and RV function worsens the systolic portion of the cardiac cycle lengthens leading to an increase in the systolic : diastolic ratio. The $\mathrm{S}: \mathrm{D}$ ratio is higher in $\mathrm{PH}$ patients than in controls $(1.38+/-0.61$ vs $0.72+/-0.16, \mathrm{p}<0.001)$, and is associated with worse echocardiographic RV fractional area change, worse catheterization hemodynamics, shorter 6-minute walk distance, and worse clinical outcomes independent of pulmonary resistance or pressures (Figure 8). ${ }^{56,60,61}$. Tissue Doppler imaging directly measures myocardial velocities and has been shown to be an accurate measure of RV and LV systolic and diastolic function. In recent pediatric studies, right ventricular TDI velocity was lower in children with PAH compared to healthy controls. ${ }^{62,63}$ Moreover, tricuspid diastolic velocity (E') had significant inverse correlations with right ventricular end-diastolic pressure and mean pulmonary arterial pressure, and cumulative event-free survival rate was significantly lower when tricuspid E' velocity was $\leq 8 \mathrm{~cm} / \mathrm{s}$ (log-rank test, $p<0.001$, Figure 9 ). ${ }^{63}$ The right ventricle contracts primarily in a longitudinal fashion, thus RV longitudinal strain measurement may play an important role in evaluation of RV function. RV longitudinal strain is a powerful tool to predict clinical outcome in adults with PH. ${ }^{64}$ Finally, real time 3dimensional echocardiography correlates well with cardiac MRI in children with congenital heart disease ${ }^{65}$ and is being evaluated in children with pulmonary hypertension.

Several additional tests may help quantitate exercise capacity and response to therapy. As in adults, the 6-minute walk (6MW) test is feasible and has been used to measure sub-maximal 
exercise. Unfortunately, the 6MW test has not been validated in children with PAH. In general, children with PAH tend to walk further than their adult counterparts with the same WHO functional class, which may be partially explained by the less frequent prevalence of right heart failure in children. Normal values for 6MWD for children have recently been published. ${ }^{66-69}$ However baseline 6MWD is not a predictor of survival, neither when expressed as an absolute distance in meters nor when adjusted to reference values expressed as $\mathrm{z}$ score or as percentage of predicted value. ${ }^{12,70}$

Cardiopulmonary exercise testing in children over 7 years of age is useful to determine peak oxygen consumption, ventilator efficiency slope (VE/VCO2), and anaerobic threshold. ${ }^{71,72}$ Ventilatory efficiency slope is significantly higher in patients with PAH, with an estimated increase of 7.2 for each increase in WHO class, and correlates strongly with invasive measures of disease severity including PAP, PVRI and outcome. ${ }^{73}$

In adults, brain natriuretic peptide (BNP) is a useful tool to assess mortality risk, progression of the disease and response to therapy. ${ }^{74}$ Recent studies in children have begun to identify usefulness of BNP or N-terminal pro brain natriuretic peptide (NT-proBNP). ${ }^{75-77}$ Furthermore, change in BNP measurements over time correlates with the change in the hemodynamic and echocardiographic parameters of children with PAH; with a BNP value > $180 \mathrm{pg} / \mathrm{ml}$ predicting a decreased survival rate (Figure 10). The change in BNP level in a specific patient over time was shown to be more helpful in determining risk or hemodynamic response to therapy than the average value in a pediatric $\mathrm{PAH}$ population. ${ }^{76}$

Although biomarkers may be used as treatment goals, to be useful treatment-induced improvements in these variables should be associated with improved survival. In the Netherlands national registry, WHO-FC, NT-proBNP and TAPSE were identified as followup predictors in which treatment-induced changes were associated with survival. Patients in whom these variables improved after treatment showed better survival. ${ }^{78}$

Newer techniques have begun to evaluate right ventricular function by determination of total right ventricular afterload by measuring impedance, cardiac MRI, and 3-dimensional echocardiography. Pulmonary vascular resistance (PVR) is the current standard for evaluating reactivity in children with pulmonary arterial hypertension (PAH). However, PVR measures only the mean component of right ventricular afterload and neglects pulsatile effects. Total right ventricular afterload can be measured as pulmonary vascular input impedance and consists of a dynamic component (compliance / stiffness) and a static component (resistance). ${ }^{79-81}$ In children, pulsatile components of right ventricular afterload, represented by pulmonary arterial capacitance and pulmonary stroke volume index, provide important prognostic information to conventional static hemodynamic parameters. ${ }^{82,83} \mathrm{RV}$ stroke work (RVSW), the product of mean pulmonary artery pressure and stroke volume, integrates contractility, afterload and ventricular-vascular coupling. RVSW can be estimated in children with PAH by echocardiography or catheterization, and is significantly associated with abnormal WHO functional class, the need for atrial septostomy, as well as mortality. ${ }^{84,85}$ Evaluation of MRI parameters in children with PAH has shown that right ventricular ejection fraction and left ventricular stroke volume index were most strongly 
predictive of survival on univariate analysis (2.6- and 2.5-fold increase in mortality for every 1-SD decrease, respectively). ${ }^{86}$

Inflammation is an important contributor to PAH in children as it is in adults. ${ }^{87,88}$ Serum amyloid A-4 (an acute phase protein released in response to inflammatory stimuli) was 4fold higher in children with poor outcome (death, initiation of intravenous prostacyclin) compared to those with good outcome (survival, discontinuation of intravenous prostacyclin) ${ }^{89}$ Interleukin-6, a proinflammatory cytokine, is associated with the occurrence of an adverse event in pediatric PH. ${ }^{90}$ Inflammatory cells, such as fibrocytes and myeloid derived suppressor cells (MDSCs) are increased in inflammatory disease and orchestrate immune cell responses. Recent published studies have shown that circulating fibrocytes and MDSCs were increased in 26 children with PAH compared to non-PAH controls. ${ }^{91}$ High levels of tissue inhibitors of metalloproteinases-1 (TIMP-1), which is overexpressed by proinflammatory cytokines, and low levels of apolipoprotein-A $1^{92}$, which reduces levels of oxidized lipids and improves vascular disease are strongly associated with outcome in pediatric PH (Figure 11). ${ }^{93}$

\section{Conventional Therapy}

Conventional therapy in patients used to treat right ventricular failure is frequently used in pulmonary arterial hypertension in children. Digoxin is used in the presence of right ventricular failure, although there are no clear-cut data in children. Furthermore, warfarin and other antithrombotic agents are used to prevent thrombosis in situ, although data specific to the pediatric population are lacking. Anticoagulation is more often used in children with IPAH and especially in those with a central venous line for intravenous prostanoid therapy or those with a hypercoagulable state. In adults and children with IPAH who receive anticoagulation, low dose warfarin is frequently used to target an INR of 1.5 to $2 .{ }^{94}$ Diuretics are used to treat peripheral edema or ascites in the presence of right heart failure, but excessive diuresis should be avoided. Careful attention to respiratory tract infections is required as this may worsen alveolar hypoxia. Routine influenza vaccination as well as pneumococcal vaccination is recommended. We recommend against the use of decongestants with pseudoephedrine or other stimulant-type medications as these have been associated with PAH. ${ }^{95}$ In children who require the use of oral contraceptive agents either for prevention of pregnancy or for regulation of menses, we recommend agents that have no estrogen content. Pulse oximetry and polysomnography is indicated and chronic hypoxemia or nighttime desaturation is aggressively treated. However, oxygen therapy is not used as a mainstay of therapy in children with normal daytime saturations. In the presence of resting hypoxemia, chronic supplemental oxygen may be used.

\section{Vasoreactivity Testing}

Cardiac catheterization with acute vasodilator testing is essential prior to selecting targeted therapy in children. Cardiac catheterization carries a greater risk in those children with baseline suprasystemic pulmonary arterial pressure (Odds Ratio $=8.1, p=0.02) .{ }^{96,97}$ In the TOPP registry complications associated with heart catheterization were analyzed in a total of 908 studies; 554 were at diagnosis and 354 in follow-up. Complications were reported in 
$5.9 \%$ with five deaths considered related to catheterization, suggesting a higher rate of catheterization complications compared to adult studies. ${ }^{47}$ As in adults, a short acting vasodilator is used, such as inhaled nitric oxide. ${ }^{2,98,99}$ It is unclear at this time whether the criteria for acute vasoreactivity are the same in adults as in children. ${ }^{2,3,100,101}$ There was no difference in the number of vasoreactivity responders in children with IPAH using the Barst or Sitbon criteria in a Netherlands study (Figure 12). ${ }^{100}$

\section{Pharmacological Therapy of PAH}

Based on known mechanisms of action, three classes of drugs have been extensively studied for the treatment of IPAH in adults: prostanoids which stimulate cAMP (epoprostenol, treprostinil, iloprost, beraprost), endothelin receptor antagonists which block endothelin (bosentan, ambrisentan, macitentan), and drugs which stimulate the nitric oxide- cyclic GMP system (phosphodiesterase inhibitors: sildenafil, tadalafil; soluble guanylate cyclase stimulators: riociguat) A pediatric specific treatment algorithm, which applies mostly to children with IPAH, was developed at the World Symposium of pulmonary hypertension in Nice 2013 and a recent adaptation is presented incorporating newer pharmaceutical therapies and surgical approaches. (Figures 8,9 ). ${ }^{4}$

\section{Calcium Channel Blockers}

The use of calcium channel antagonists to evaluate vasoreactivity is dangerous, as these drugs can cause a decrease in cardiac output or a marked drop in systemic blood pressure. Such deleterious effects may be prolonged due to the relatively long half-life of calcium channel blockers. Consequently, elevated right atrial pressure and low cardiac output are contraindications to acute or chronic calcium channel blockade. Recent data have shown that $10-35 \%$ of children with IPAH are responders to acute vasodilator testing. ${ }^{4,15,100,102}$

Our preference is to perform an acute trial of calcium channel blocker therapy only in those patients who are acutely responsive to either nitric oxide or prostacyclin. Likewise, patients who do not have an acute vasodilatory response to short acting agents and who are then placed on calcium channel blocker therapy are unlikely to benefit from this form of therapy. ${ }^{2}$ Recent study examined a previously identified cohort of 77 children diagnosed between 1982 and 1995 with idiopathic pulmonary arterial hypertension and followed up through 2002. For acute responders treated with CCB ( $\mathrm{n}=31)$, survival at 1,5 , and 10 years was $97 \%$, $97 \%$, and $81 \%$, respectively; treatment success was $84 \%, 68 \%$, and $47 \%$, respectively (Figure 10). ${ }^{103}$ Sixty to eighty percent of children with severe pulmonary hypertension are non-responsive to acute vasodilator testing, and therefore require therapy other than calcium channel antagonists. Children and adults treated with calcium channel blockers may loose this response over time and must be monitored carefully for sustained efficacy (Figure 14). ${ }^{2,103}$

\section{Prostacyclins}

Adults with IPAH and children with congenital heart disease demonstrate an imbalance in the biosynthesis of thromboxane $\mathrm{A}_{2}$ and prostacyclin. ${ }^{104,105}$ Likewise, adults and children 
with severe pulmonary hypertension show diminished prostacyclin synthase expression in the lung vasculature. ${ }^{106}$ Prostacyclin administered over the long term, utilizing intravenous epoprostenol, has shown to improve survival and quality of life in adults and children with idiopathic pulmonary arterial hypertension. ${ }^{2,3,103,107-109}$

Prostacyclin and prostacyclin analogues impact the cyclic-AMP pathway to increase pulmonary vasodilation. Intravenous epoprostenol-prostacyclin was first used in the 1980s and continues to be the gold standard for treatment of severe disease. Epoprostenol was FDA approved in 1995. Seventy-seven children diagnosed between 1982 and 1995 with idiopathic pulmonary arterial hypertension were followed up through 2002. Survival for all children treated with epoprostenol $(\mathrm{n}=35)$ at 1,5 , and 10 years was $94 \%, 81 \%$, and $61 \%$, respectively, while treatment success was $83 \%, 57 \%$, and $37 \%$, respectively(Figure 15). ${ }^{103}$ The dose of intravenous prostacyclin in young children is usually higher than adults.

The prostacyclin analogue, treprostinil was approved by the FDA, initially for subcutaneous use (2002), intravenous administration (2004), inhaled administration (2009), and oral treatment (2013). While subcutaneous treprostinil allows patients to remain free of central venous catheters, it can cause severe pain at the infusion site. Long term efficacy of subcutaneous treprostinil ${ }^{110}$ and intravenous treprostinil ${ }^{111}$ has been evaluated in adults with $\mathrm{PAH}$. Intravenous treprostinil requires central line access and continuous infusion, but is easier for families to mix, may be used at room temperature, and has a half-life of four hours. Intravenous treprostinil has fewer side effects than intravenous epoprostenol, but there are no studies comparing efficacy. ${ }^{112}$ Some studies have suggested a higher rate of bacteremia in children and adults treated with intravenous treprostinil, ${ }^{113}$ but this may be decreased by protecting catheter connections and avoiding water on any connection. ${ }^{114}$ Subcutaneous treprostinil in young children is well tolerated in many children with tolerable side effects. ${ }^{15,116}$ Treprostinil has also been studied in an inhaled form. ${ }^{17-119}$ Oral treprostinil was shown to effective as initial monotherapy treatment in adult $\mathrm{PAH}^{120}$, but not as add-on therapy. ${ }^{121}$ Studies using oral treprostinil in children are ongoing.

Iloprost, an inhaled prostacyclin analogue, received approval for the treatment of PAH in the United States in December 2004. This medication is administered by nebulization 6-9 times a day. Iloprost requires patient cooperation with the treatment administration lasting 10-15 minutes ${ }^{122}$, which is difficult for young children. ${ }^{123}$ In the acute setting, inhaled iloprost lowers mean pulmonary artery pressure and improves systemic oxygen saturation. ${ }^{124}$ Some children may develop reactive airways obstruction limiting usefulness of this therapy.

\section{Endothelin Receptor Antagonists}

Another target for treatment of pulmonary hypertension is the vasoconstrictor peptide endothelin (ET). ${ }^{125}$ The endothelins are a family of isopeptides consisting of ET-1, ET-2, and ET-3. ET-1 is a potent vasoactive peptide produced primarily in the vascular endothelial cell, but also may be produced by smooth muscle cells. Two receptor subtypes, $\mathrm{ET}_{\mathrm{A}}$ and $\mathrm{ET}_{\mathrm{B}}$, mediate the activity of $\mathrm{ET}-1 . \mathrm{ET}_{\mathrm{A}}$ and $\mathrm{ET}_{\mathrm{B}}$ receptors on vascular smooth muscle mediate vasoconstriction, whereas $\mathrm{ET}_{\mathrm{B}}$ receptors on endothelial cells cause release of nitric oxide (NO) and prostacyclin (PGI2), and act as clearance receptors for circulating ET-1. 
ET-1 expression is increased in the pulmonary arteries of patients with pulmonary hypertension.

Bosentan, a dual ET receptor antagonist, lowers pulmonary artery pressure and resistance, and improves exercise tolerance in adults with pulmonary arterial hypertension. ${ }^{125}$ Bosentan has been approved since 2001 for the treatment of WHO functional Class III and IV patients over 12 years of age, and has recently shown beneficial effects in Class II patients. ${ }^{126}$ These results have been extrapolated to children. ${ }^{109,127-134}$ Bosentan therapy added on to epoprostenol in children allowed for a decrease in epoprostenol dose and its associated side effects. ${ }^{109}$ A more recent retrospective study of 86 children on bosentan for a median exposure of 14 months with and without concomitant therapy found that bosentan as part of an overall treatment strategy provided a sustained clinical and hemodynamic improvement was overall well tolerated, and two year survival estimates were $91 \%$. In this study, $90 \%$ improved or remained unchanged in WHO FC after median treatment duration of 14 months. ${ }^{133}$ Comparable results were reported by Maiya et al., except that in IPAH stabilization was achieved in $95 \%$ but combined therapy with epoprostenol was necessary in $60 \% .{ }^{132}$ Elevated hepatic aminotransferase levels occur in approximately $12 \%$ of adults treated with bosentan but were only $3.5 \%$ in children. ${ }^{133}$ Recently, a European, prospective, noninterventional, internet-based post marketing surveillance database of bosentan was evaluated. Pediatric patients (aged 2-11 years) were compared with patients over 12 years of age. Over a 30-month period, 4994 patients, including 146 bosentan-naive pediatric patients, were captured in the database. PAH was idiopathic in $40 \%$ and related to congenital heart disease in $45 \%$. The median exposure to bosentan was 29.1 weeks, and elevated aminotransferases were reported in $2.7 \%$ of children less than 12 years of age versus $7.8 \%$ in older patients. The discontinuation rate was $14.4 \%$ in children versus $28.1 \%$ in patients over 12 years. ${ }^{131}$ A pediatric formulation of bosentan is approved in Europe. ${ }^{129}$ Macitentan, a dual endothelin-receptor antagonist, was FDA approved in 2013. Macitentan reduced the time from the initiation of treatment to the first occurrence of a composite end point of death, atrial septostomy, lung transplantation, initiation of treatment with intravenous or subcutaneous prostanoids, or worsening of pulmonary arterial hypertension. ${ }^{135}$

Selective $\mathrm{ET}_{\mathrm{A}}$ receptor blockade using ambrisentan may benefit patients with pulmonary arterial hypertension by blocking the vasoconstrictor effects of $\mathrm{ET}_{\mathrm{A}}$ receptors while maintaining the vasodilator/clearance functions of $\mathrm{ET}_{\mathrm{B}}$ receptors. Ambrisentan was approved by the U.S. FDA in June 2007. Adults showed significant improvements in 6minute walk distance and significant delay in clinical worsening on ambrisentan. The incidence of elevated hepatic aminotransferase levels was $2.8 \% .^{136}$ Initial experience with ambrisentan in children suggests that treatment is safe with similar pharmacokinetics to those in adults and may improve PAH in some children. ${ }^{137,138}$

\section{Phosphodiesterase-5 Inhibitors and Soluble Guanylate cyclase Stimulators}

In models of PAH, phosphodiesterase-5 activity is increased and protein is localized to vascular smooth muscle. ${ }^{139}$ Specific phosphodiesterase-5 inhibitors, such as 
sildenafil, ${ }^{140,141}$ and tadalafil ${ }^{142-145}$ promote an increase in cGMP levels and thus promote pulmonary vasodilation and remodeling. In certain settings, intravenous sildenafil may worsen oxygenation. ${ }^{146,147}$ Sildenafil has been shown to prevent rebound PAH on withdrawal from inhaled NO. ${ }^{148,149}$ Addition of sildenafil to long-term intravenous epoprostenol therapy in adults with PAH has been shown to be beneficial. ${ }^{126}$

Sildenafil has been approved for the treatment of WHO functional class II-IV PAH adult patients. ${ }^{141}$ Sildenafil has been extensively studied in children with PAH. ${ }^{140,150-153}$ In the 16-week, randomized, double-blind study, STARTS-1, the effects of oral sildenafil in pediatric PAH were studied. ${ }^{154}$ Children $(\mathrm{n}=235)$ with PAH (aged 1-17 yrs.; $\geq 8 \mathrm{~kg}$ ) received low-, medium-, or high-dose sildenafil or placebo orally three times daily. The trial did not meet its primary endpoint as estimated mean \pm standard error percentage change in $\mathrm{pVO}_{2}$ for the low-, medium- and high-doses combined versus placebo was $7.7 \% \pm 4.0 \%$ (95\% CI, $-0.2 \%$ to $15.6 \%$; $P=0.056$; Figure 9). ${ }^{154}$ After the initial 16 week study, patients in the low-, medium-, and high-dose groups remained on that dose. ${ }^{155}$ Patients in the placebo group were randomized to low, medium, or high dose; patients were then followed for the duration of the study. By 3 years, the hazard ratio for mortality was 3.95 (95\% confidence interval, 1.46-10.65) for high vs. low dose. Most patients who died had idiopathic/heritable PAH (76\% vs $33 \%$ overall) and baseline functional class III/IV disease ( $38 \%$ vs. $15 \%$ overall); patients who died had worse baseline hemodynamics. Kaplan-Meier estimated 3-year survival rates from the start of sildenafil were $94 \%, 93 \%$, and $88 \%$ for patients randomized to low-, medium-, and high-dose sildenafil (Figure 16). Based on this, the data monitoring committee recommended that all patients down-titrate from the high dose. Review of the STARTS- 1 and -2 by the FDA and the European Medicines Agency (EMA) resulted in disparate recommendations. Sildenafil was approved by the EMA in 2011, with a later warning on avoidance of use of the high dose. In August 2012, the FDA released a strong warning against the (chronic) use of sildenafil for pediatric patients (ages 1 through 17) with PAH (http://www.fda.gov/Safety/MedWatch/SafetyInformation/ SafetyAlertsforHumanMedicalProducts/ucm317743.htm). In 2014, the FDA clarified the sildenafil warning, stating that there may be situations in which the risk-benefit profile of Revatio may be acceptable in individual children, and that sildenafil is still not recommended in children with PH. (http://www.fda.gov/Drugs/DrugSafety/ ucm390876.htm).

Tadalalfil, another selective phosphodiesterase type 5 inhibitor, has a longer duration of action. In a study of 33 children with PAH, 29 were switched from sildenafil to tadalafil primarily for once-daily dosing. The average dose of sildenafil was $3.4+/-1.1 \mathrm{mg} / \mathrm{kg} / \mathrm{day}$, and that of tadalafil was $1.0+/-0.4 \mathrm{mg} / \mathrm{kg} /$ day. For 14 of the 29 patients undergoing repeat catheterization, statistically significant improvements were observed after transition from sildenafil to tadalafil in terms of PAP and PVRI. Tadalafil was well tolerated, except in 2 children who discontinued for migraine or allergic reaction, and appeared to slow disease progression. ${ }^{142}$

Stimulation of the NO-cGMP pathway has revolutionized care of the patient with PH. Riociguat, a direct oral soluble guanylate cyclase (sGC) stimulator, increases cGMP directly in a non-NO dependent manner but also increases the sensitivity of sGC to NO. ${ }^{156}$ Riociguat 
was approved by the FDA in 2013 for treatment of adult $\mathrm{PAH}^{157}$ and is the first FDA

approved drug for the treatment of chronic thromboembolic PH. ${ }^{158}$

\section{Combination Therapy}

By targeting multiple pathways, combination therapy is appealing as treatment in more severe disease. Between 2000 and 2010, pediatric patients with PAH were compared between 3 centers. Treatment with PAH-targeted combination therapy during the study period was independently and strongly associated with improved survival compared to monotherapy (Figure 17). ${ }^{3}$

\section{Atrial Septostomy and Potts Shunt for Refractory PAH}

The general indications for atrial septostomy include pulmonary hypertension, syncope and intractable heart failure refractory to chronic vasodilator treatment and symptomatic low cardiac output states. ${ }^{159-162}$ Risks associated with this procedure include worsening of hypoxemia with resultant right ventricular ischemia, worsening right ventricular failure, increased left atrial pressure, and pulmonary edema. We favor a graded balloon dilation approach utilizing intracardiac echo and saturation monitoring to determine adequacy of shunt. Recently, a Potts anastomosis with connection of the left pulmonary artery to descending aorta, has been attempted to allow a direct shunt allowing an immediate reduction in right ventricular afterload. ${ }^{163-165}$ A Potts shunt may unload the right ventricle in systole whereas an atrial septostomy provides a diastolic unloading. Treatment of right heart failure with the Potts shunt is increasing (Figure 18).

\section{Transplantation}

For patients who do not respond to prolonged vasodilator treatment, lung transplantation should be considered. ${ }^{166-168}$ Cystic fibrosis accounts for the majority of pediatric lung transplants. IPAH is the second most-common indication for lung transplant in pediatric patients overall, and is the most common indication among children aged 1-5 years. ${ }^{169}$ Overall survival following pediatric lung transplant is similar to that encountered in adult patients, with recent registry data indicating a median survival of 4.9 years. ${ }^{169-171}$ The most common causes of post-transplant death include graft failure, technical issues and infection, whereas infection and bronchiolitis obliterans syndrome are the most common causes of late death.

\section{Conclusion}

The prevalence of $\mathrm{PH}$ is increasing in the pediatric population, due to improved recognition and increased survival of patients, and remains a significant cause of morbidity and mortality. Recent studies have improved understanding of pediatric PH but management remains challenging due to lack of evidence based clinical trials. The growing contribution of developmental lung disease requires dedicated research to explore use of existing therapies as well as creation of novel therapies. Adequate study of pediatric $\mathrm{PH}$ will require multicenter collaboration due to the small numbers of patients, multifactorial disease etiologies and practice variability. 


\section{References}

1. D'Alonzo GE, Barst RJ, Ayres SM, et al. Survival in patients with primary pulmonary hypertension. Results from a national prospective registry. Ann Intern Med. 1991; 115:343-349. [PubMed: 1863023]

2. Barst RJ, Maislin G, Fishman AP. Vasodilator therapy for primary pulmonary hypertension in children. Circulation. 1999; 99:1197-1208. [PubMed: 10069788]

3. Zijlstra WM, Douwes JM, Rosenzweig EB, et al. Survival differences in pediatric pulmonary arterial hypertension: clues to a better understanding of outcome and optimal treatment strategies. J Am Coll Cardiol. 2014; 63:2159-2169. [PubMed: 24681143]

4. Ivy DD, Abman SH, Barst RJ, et al. Pediatric pulmonary hypertension. J Am Coll Cardiol. 2013; 62:D117-D126. [PubMed: 24355636]

5. Barst RJ, Ertel SI, Beghetti M, Ivy DD. Pulmonary arterial hypertension: a comparison between children and adults. Eur Respir J. 2011; 37:665-677. [PubMed: 21357924]

6. Cerro MJ, Abman S, Diaz G, et al. A consensus approach to the classification of pediatric pulmonary hypertensive vascular disease: Report from the PVRI Pediatric Taskforce, Panama 2011. Pulm Circ. 2011; 1:286-298. [PubMed: 21874158]

7. Galie N, Corris PA, Frost A, et al. Updated treatment algorithm of pulmonary arterial hypertension. J Am Coll Cardiol. 2013; 62:D60-D72. [PubMed: 24355643]

8. Galie N, Humbert M, Vachiery JL, et al. 2015 ESC/ERS Guidelines for the diagnosis and treatment of pulmonary hypertension: The Joint Task Force for the Diagnosis and Treatment of Pulmonary Hypertension of the European Society of Cardiology (ESC) and the European Respiratory Society (ERS): Endorsed by: Association for European Paediatric and Congenital Cardiology (AEPC), International Society for Heart and Lung Transplantation (ISHLT). Eur Respir J. 2015

9. Baruteau AE, Belli E, Boudjemline Y, et al. Palliative Potts shunt for the treatment of children with drug-refractory pulmonary arterial hypertension: updated data from the first 24 patients. Eur $\mathbf{J}$ Cardiothorac Surg. 2015; 47:e105-e110. [PubMed: 25475943]

10. Hoeper MM, Bogaard HJ, Condliffe R, et al. Definitions and diagnosis of pulmonary hypertension. J Am Coll Cardiol. 2013; 62:D42-D50. [PubMed: 24355641]

11. Simonneau G, Gatzoulis MA, Adatia I, et al. Updated clinical classification of pulmonary hypertension. J Am Coll Cardiol. 2013; 62:D34-D41. [PubMed: 24355639]

12. Moledina S, Hislop AA, Foster H, Schulze-Neick I, Haworth SG. Childhood idiopathic pulmonary arterial hypertension: a national cohort study. Heart. 2010; 96:1401-1406. [PubMed: 20406768]

13. van Loon RL, Roofthooft MT, Hillege HL, et al. Pediatric Pulmonary Hypertension in the Netherlands: Epidemiology and Characterization During the Period 1991 to 2005. Circulation. 2011

14. Cerro Marin MJ, Sabate Rotes A, Rodriguez Ogando A, et al. Assessing Pulmonary Hypertensive Vascular Disease in Childhood: Data from the Spanish Registry. Am J Respir Crit Care Med. 2014

15. Haworth SG, Hislop AA. Treatment and survival in children with pulmonary arterial hypertension: the UK Pulmonary Hypertension Service for Children 2001-2006. Heart. 2009; 95:312-317. [PubMed: 18952635]

16. Maxwell BG, Nies MK, Ajuba-Iwuji CC, Coulson JD, Romer LH. Trends in Hospitalization for Pediatric Pulmonary Hypertension. Pediatrics. 2015; 136:241-250. [PubMed: 26148956]

17. Frank DB, Crystal MA, Morales DL, et al. Trends in pediatric pulmonary hypertension-related hospitalizations in the United States from 2000-2009. Pulm Circ. 2015; 5:339-348. [PubMed: 26064460]

18. Austin ED, Loyd JE. The genetics of pulmonary arterial hypertension. Circ Res. 2014; 115:189202. [PubMed: 24951767]

19. Soubrier F, Chung WK, Machado R, et al. Genetics and genomics of pulmonary arterial hypertension. J Am Coll Cardiol. 2013; 62:D13-D21. [PubMed: 24355637]

20. Rosenzweig EB, Morse JH, Knowles JA, et al. Clinical implications of determining BMPR2 mutation status in a large cohort of children and adults with pulmonary arterial hypertension. $\mathrm{J}$ Heart Lung Transplant. 2008; 27:668-674. [PubMed: 18503968] 
21. Harrison RE, Berger R, Haworth SG, et al. Transforming growth factor-beta receptor mutations and pulmonary arterial hypertension in childhood. Circulation. 2005; 111:435-441. [PubMed: 15687131]

22. Lane KB, Machado RD, Pauciulo MW, et al. Heterozygous germline mutations in BMPR2, encoding a TGF-beta receptor, cause familial primary pulmonary hypertension. The International PPH Consortium. Nature genetics. 2000; 26:81-84. [PubMed: 10973254]

23. Deng Z, Morse JH, Slager SL, et al. Familial primary pulmonary hypertension (gene PPH1) is caused by mutations in the bone morphogenetic protein receptor-II gene. Am J Hum Genet. 2000; 67:737-744. [PubMed: 10903931]

24. Grunig E, Koehler R, Miltenberger-Miltenyi G, et al. Primary pulmonary hypertension in children may have a different genetic background than in adults. Pediatr Res. 2004; 56:571-578. [PubMed: 15295086]

25. Fujiwara M, Yagi H, Matsuoka R, et al. Implications of mutations of activin receptor-like kinase 1 gene (ALK1) in addition to bone morphogenetic protein receptor II gene (BMPR2) in children with pulmonary arterial hypertension. Circ J. 2008; 72:127-133. [PubMed: 18159113]

26. Ma L, Chung WK. The genetic basis of pulmonary arterial hypertension. Human genetics. 2014; 133:471-479. [PubMed: 24442418]

27. Best DH, Austin ED, Chung WK, Elliott CG. Genetics of pulmonary hypertension. Curr Opin Cardiol. 2014; 29:520-527. [PubMed: 25159282]

28. Kerstjens-Frederikse WS, Bongers EM, Roofthooft MT, et al. TBX4 mutations (small patella syndrome) are associated with childhood-onset pulmonary arterial hypertension. J Med Genet. 2013; 50:500-506. [PubMed: 23592887]

29. La Gerche A, Gewillig M. What Limits Cardiac Performance during Exercise in Normal Subjects and in Healthy Fontan Patients? Int J Pediatr. 2010; 2010

30. John AS, Johnson JA, Khan M, Driscoll DJ, Warnes CA, Cetta F. Clinical outcomes and improved survival in patients with protein-losing enteropathy after the Fontan operation. J Am Coll Cardiol. 2014; 64:54-62. [PubMed: 24998129]

31. Haseyama K, Satomi G, Yasukochi S, Matsui H, Harada Y, Uchita S. Pulmonary vasodilation therapy with sildenafil citrate in a patient with plastic bronchitis after the Fontan procedure for hypoplastic left heart syndrome. J Thorac Cardiovasc Surg. 2006; 132:1232-1233. [PubMed: 17059953]

32. Malhotra SP, Ivy DD, Mitchell MB, et al. Performance of cavopulmonary palliation at elevated altitude: midterm outcomes and risk factors for failure. Circulation. 2008; 118:S177-S181. [PubMed: 18824752]

33. Levy M, Danel C, Laval AM, Leca F, Vouhe PR, Israel-Biet D. Nitric oxide synthase expression by pulmonary arteries: a predictive marker of Fontan procedure outcome? J Thorac Cardiovasc Surg. 2003; 125:1083-1090. [PubMed: 12771882]

34. Mitchell MB, Campbell DN, Ivy D, et al. Evidence of pulmonary vascular disease after heart transplantation for Fontan circulation failure. J Thorac Cardiovasc Surg. 2004; 128:693-702. [PubMed: 15514596]

35. Van De Bruaene A, La Gerche A, Claessen G, et al. Sildenafil improves exercise hemodynamics in Fontan patients. Circ Cardiovasc Imaging. 2014; 7:265-273. [PubMed: 24478333]

36. Goldberg DJ, French B, Szwast AL, et al. Impact of sildenafil on echocardiographic indices of myocardial performance after the Fontan operation. Pediatr Cardiol. 2012; 33:689-696. [PubMed: 22331056]

37. Morchi GS, Ivy DD, Duster MC, Claussen L, Chan KC, Kay J. Sildenafil Increases Systemic Saturation and Reduces Pulmonary Artery Pressure in Patients with Failing Fontan Physiology. Congenit Heart Dis. 2009; 4:107-111. [PubMed: 21866231]

38. Yamagishi M, Kurosawa H, Hashimoto K, Nomura K, Kitamura N. The role of plasma endothelin in the Fontan circulation. J Cardiovasc Surg (Torino). 2002; 43:793-797.

39. Hebert A, Mikkelsen UR, Thilen U, et al. Bosentan improves exercise capacity in adolescents and adults after Fontan operation: the TEMPO (Treatment With Endothelin Receptor Antagonist in Fontan Patients, a Randomized, Placebo-Controlled, Double-Blind Study Measuring Peak Oxygen Consumption) study. Circulation. 2014; 130:2021-2030. [PubMed: 25446057] 
40. Derk G, Houser L, Miner P, et al. Efficacy of Endothelin Blockade in Adults with Fontan Physiology. Congenit Heart Dis. 2014

41. Bowater SE, Weaver RA, Thorne SA, Clift PF. The safety and effects of bosentan in patients with a Fontan circulation. Congenit Heart Dis. 2012; 7:243-249. [PubMed: 22348734]

42. Krishnan U, Rosenzweig EB. Pulmonary hypertension in chronic lung disease of infancy. Curr Opin Pediatr. 2015; 27:177-183. [PubMed: 25689457]

43. Mourani PM, Sontag MK, Younoszai A, et al. Early pulmonary vascular disease in preterm infants at risk for bronchopulmonary dysplasia. Am J Respir Crit Care Med. 2015; 191:87-95. [PubMed: 25389562]

44. Abman SH, Hansmann G, Archer SL, et al. Pediatric Pulmonary Hypertension: Guidelines From the American Heart Association and American Thoracic Society. Circulation. 2015

45. del Cerro MJ, Sabate Rotes A, Carton A, et al. Pulmonary hypertension in bronchopulmonary dysplasia: clinical findings, cardiovascular anomalies and outcomes. Pediatr Pulmonol. 2014; 49:49-59. [PubMed: 23788443]

46. Khemani E, McElhinney DB, Rhein L, et al. Pulmonary artery hypertension in formerly premature infants with bronchopulmonary dysplasia: clinical features and outcomes in the surfactant era. Pediatrics. 2007; 120:1260-1269. [PubMed: 18055675]

47. Beghetti M, Berger RM, Schulze-Neick I, et al. Diagnostic evaluation of paediatric pulmonary hypertension in current clinical practice. Eur Respir J. 2013; 42:689-700. [PubMed: 23563261]

48. Jone PN, Ivy DD. Echocardiography in pediatric pulmonary hypertension. Frontiers in pediatrics. 2014; 2:124. [PubMed: 25429362]

49. Forfia PR, Fisher MR, Mathai SC, et al. Tricuspid annular displacement predicts survival in pulmonary hypertension. Am J Respir Crit Care Med. 2006; 174:1034-1041. [PubMed: 16888289]

50. Galie N, Hinderliter AL, Torbicki A, et al. Effects of the oral endothelin-receptor antagonist bosentan on echocardiographic and doppler measures in patients with pulmonary arterial hypertension. Journal of the American College of Cardiology. 2003; 41:1380-1386. [PubMed: 12706935]

51. Hinderliter AL, Willis PWt, Barst RJ, et al. Effects of long-term infusion of prostacyclin (epoprostenol) on echocardiographic measures of right ventricular structure and function in primary pulmonary hypertension. Primary Pulmonary Hypertension Study Group. Circulation. 1997; 95:1479-1486. [PubMed: 9118516]

52. Koestenberger M, Ravekes W, Everett AD, et al. Right ventricular function in infants, children and adolescents: reference values of the tricuspid annular plane systolic excursion (TAPSE) in 640 healthy patients and calculation of z score values. J Am Soc Echocardiogr. 2009; 22:715-719. [PubMed: 19423286]

53. Raymond RJ, Hinderliter AL, Willis PW, et al. Echocardiographic predictors of adverse outcomes in primary pulmonary hypertension. Journal of the American College of Cardiology. 2002; 39:1214-1219. [PubMed: 11923049]

54. Tei C, Dujardin KS, Hodge DO, et al. Doppler echocardiographic index for assessment of global right ventricular function. Journal of the American Society of Echocardiography : official publication of the American Society of Echocardiography. 1996; 9:838-847. [PubMed: 8943444]

55. Dyer KL, Pauliks LB, Das B, et al. Use of myocardial performance index in pediatric patients with idiopathic pulmonary arterial hypertension. J Am Soc Echocardiogr. 2006; 19:21-27. [PubMed: 16423665]

56. Kassem E, Humpl T, Friedberg MK. Prognostic significance of 2-dimensional, M-mode, and Doppler echo indices of right ventricular function in children with pulmonary arterial hypertension. Am Heart J. 2013; 165:1024-1031. [PubMed: 23708176]

57. Jone PN, Hinzman J, Wagner BD, Ivy DD, Younoszai A. Right ventricular to left ventricular diameter ratio at end-systole in evaluating outcomes in children with pulmonary hypertension. $\mathrm{J}$ Am Soc Echocardiogr. 2014; 27:172-178. [PubMed: 24325962]

58. Masuyama T, Kodama K, Kitabatake A, Sato H, Nanto S, Inoue M. Continuous-wave Doppler echocardiographic detection of pulmonary regurgitation and its application to noninvasive estimation of pulmonary artery pressure. Circulation. 1986; 74:484-492. [PubMed: 2943530] 
59. Benza RL, Miller DP, Gomberg-Maitland M, et al. Predicting survival in pulmonary arterial hypertension: insights from the Registry to Evaluate Early and Long-Term Pulmonary Arterial Hypertension Disease Management (REVEAL). Circulation. 2010; 122:164-172. [PubMed: 20585012]

60. Alkon J, Humpl T, Manlhiot C, McCrindle BW, Reyes JT, Friedberg MK. Usefulness of the right ventricular systolic to diastolic duration ratio to predict functional capacity and survival in children with pulmonary arterial hypertension. The American journal of cardiology. 2010; 106:430-436. [PubMed: 20643259]

61. Friedberg MK, Redington AN. Right versus left ventricular failure: differences, similarities, and interactions. Circulation. 2014; 129:1033-1044. [PubMed: 24589696]

62. Lammers AE, Haworth SG, Riley G, Maslin K, Diller GP, Marek J. Value of tissue Doppler echocardiography in children with pulmonary hypertension. J Am Soc Echocardiogr. 2012; 25:504-510. [PubMed: 22365880]

63. Takatsuki S, Nakayama T, Jone PN, et al. Tissue Doppler imaging predicts adverse outcome in children with idiopathic pulmonary arterial hypertension. J Pediatr. 2012; 161:1126-1131. [PubMed: 22748515]

64. Ozawa K, Funabashi N, Takaoka H, et al. Utility of three-dimensional global longitudinal strain of the right ventricle using transthoracic echocardiography for right ventricular systolic function in pulmonary hypertension. Int J Cardiol. 2014; 174:426-430. [PubMed: 24774355]

65. Lu X, Nadvoretskiy V, Bu L, et al. Accuracy and reproducibility of real-time three-dimensional echocardiography for assessment of right ventricular volumes and ejection fraction in children. $\mathrm{J}$ Am Soc Echocardiogr. 2008; 21:84-89. [PubMed: 17628408]

66. Geiger R, Strasak A, Treml B, et al. Six-minute walk test in children and adolescents. J Pediatr. 2007; 150:395-399. 9 e1-9 e2. [PubMed: 17382117]

67. Lammers AE, Hislop AA, Flynn Y, Haworth SG. The 6-minute walk test: normal values for children of 4-11 years of age. Arch Dis Child. 2008; 93:464-468. [PubMed: 17675356]

68. Lesser DJ, Fleming MM, Maher CA, Kim SB, Woo MS, Keens TG. Does the 6-min walk test correlate with the exercise stress test in children? Pediatric pulmonology. 2010; 45:135-140. [PubMed: 20082339]

69. Li AM, Yin J, Au JT, et al. Standard reference for the six-minute-walk test in healthy children aged 7 to 16 years. Am J Respir Crit Care Med. 2007; 176:174-180. [PubMed: 17463419]

70. van Loon RL, Roofthooft MT, Delhaas T, et al. Outcome of pediatric patients with pulmonary arterial hypertension in the era of new medical therapies. Am J Cardiol. 2010; 106:117-124. [PubMed: 20609658]

71. Garofano RP, Barst RJ. Exercise testing in children with primary pulmonary hypertension. Pediatr Cardiol. 1999; 20:61-64. discussion 5. [PubMed: 9861081]

72. Yetman AT, Taylor AL, Doran A, Ivy DD. Utility of cardiopulmonary stress testing in assessing disease severity in children with pulmonary arterial hypertension. Am J Cardiol. 2005; 95:697699. [PubMed: 15721127]

73. Rausch CM, Taylor AL, Ross H, Sillau S, Ivy DD. Ventilatory efficiency slope correlates with functional capacity, outcomes, and disease severity in pediatric patients with pulmonary hypertension. Int J Cardiol. 2013; 169:445-448. [PubMed: 24144928]

74. Nagaya N, Nishikimi T, Uematsu M, et al. Plasma brain natriuretic peptide as a prognostic indicator in patients with primary pulmonary hypertension. Circulation. 2000; 102:865-870. [PubMed: 10952954]

75. Lammers AE, Hislop AA, Haworth SG. Prognostic value of B-type natriuretic peptide in children with pulmonary hypertension. Int J Cardiol. 2009; 135:21-26. [PubMed: 18599134]

76. Bernus A, Wagner BD, Accurso F, Doran A, Kaess H, Ivy DD. Brain natriuretic peptide levels in managing pediatric patients with pulmonary arterial hypertension. Chest. 2009; 135:745-751. [PubMed: 18849405]

77. Van Albada ME, Loot FG, Fokkema R, Roofthooft MT, Berger RM. Biological serum markers in the management of pediatric pulmonary arterial hypertension. Pediatr Res. 2008; 63:321-327. [PubMed: 18287971] 
78. Ploegstra MJ, Douwes JM, Roofthooft MT, Zijlstra WM, Hillege HL, Berger RM. Identification of treatment goals in paediatric pulmonary arterial hypertension. Eur Respir J. 2014

79. Su Z, Tan W, Shandas R, Hunter KS. Influence of distal resistance and proximal stiffness on hemodynamics and RV afterload in progression and treatments of pulmonary hypertension: a computational study with validation using animal models. Computational and mathematical methods in medicine. 2013; 2013:618326. [PubMed: 24367392]

80. Su Z, Hunter KS, Shandas R. Impact of pulmonary vascular stiffness and vasodilator treatment in pediatric pulmonary hypertension: 21 patient-specific fluid-structure interaction studies. Computer methods and programs in biomedicine. 2012; 108:617-628. [PubMed: 21975085]

81. Hunter KS, Feinstein JA, Ivy DD, Shandas R. Computational Simulation of the Pulmonary Arteries and its Role in the Study of Pediatric Pulmonary Hypertension. Prog Pediatr Cardiol. 2010; 30:6369. [PubMed: 21499523]

82. Friedberg MK, Feinstein JA, Rosenthal DN. Noninvasive assessment of pulmonary arterial capacitance by echocardiography. J Am Soc Echocardiogr. 2007; 20:186-190. [PubMed: 17275705]

83. Douwes JM, Roofthooft MT, Bartelds B, Talsma MD, Hillege HL, Berger RM. Pulsatile haemodynamic parameters are predictors of survival in paediatric pulmonary arterial hypertension. Int J Cardiol. 2013; 168:1370-1377. [PubMed: 23340486]

84. Di Maria MV, Younoszai AK, Mertens L, et al. RV stroke work in children with pulmonary arterial hypertension: estimation based on invasive haemodynamic assessment and correlation with outcomes. Heart. 2014; 100:1342-1347. [PubMed: 24780910]

85. Di Maria MV, Burkett DA, Younoszai AK, et al. Echocardiographic Estimation of Right Ventricular Stroke Work in Children with Pulmonary Arterial Hypertension: Comparison with Invasive Measurements. J Am Soc Echocardiogr. 2015

86. Moledina S, Pandya B, Bartsota M, et al. Prognostic significance of cardiac magnetic resonance imaging in children with pulmonary hypertension. Circ Cardiovasc Imaging. 2013; 6:407-414. [PubMed: 23572488]

87. Hall S, Brogan P, Haworth SG, Klein N. Contribution of inflammation to the pathology of idiopathic pulmonary arterial hypertension in children. Thorax. 2009; 64:778-783. [PubMed: 19525266]

88. Nies MK, Ivy DD, Everett AD. The untapped potential of proteomic analysis in pediatric pulmonary hypertension. Proteomics Clinical applications. 2014

89. Yeager ME, Colvin KL, Everett AD, Stenmark KR, Ivy DD. Plasma proteomics of differential outcome to long-term therapy in children with idiopathic pulmonary arterial hypertension. Proteomics Clinical applications. 2012; 6:257-267. [PubMed: 22653875]

90. Duncan M, Wagner BD, Murray K, et al. Circulating cytokines and growth factors in pediatric pulmonary hypertension. Mediators of inflammation. 2012; 2012:143428. [PubMed: 23316102]

91. Yeager ME, Nguyen CM, Belchenko DD, et al. Circulating myeloid-derived suppressor cells are increased and activated in pulmonary hypertension. Chest. 2012; 141:944-952. [PubMed: 21940769]

92. Sharma S, Umar S, Potus F, et al. Apolipoprotein A-I mimetic peptide 4F rescues pulmonary hypertension by inducing microRNA-193-3p. Circulation. 2014; 130:776-785. [PubMed: 24963038]

93. Wagner BD, Takatsuki S, Accurso FJ, Ivy DD. Evaluation of circulating proteins and hemodynamics towards predicting mortality in children with pulmonary arterial hypertension. PLoS One. 2013; 8:e80235. [PubMed: 24278261]

94. Olsson KM, Delcroix M, Ghofrani HA, et al. Anticoagulation and survival in pulmonary arterial hypertension: results from the Comparative, Prospective Registry of Newly Initiated Therapies for Pulmonary Hypertension (COMPERA). Circulation. 2014; 129:57-65. [PubMed: 24081973]

95. Barst RJ, Abenhaim L. Fatal pulmonary arterial hypertension associated with phenylpropanolamine exposure. Heart. 2004; 90:e42. [PubMed: 15201268]

96. Friesen RH, Williams GD. Anesthetic management of children with pulmonary arterial hypertension. Paediatr Anaesth. 2008; 18:208-216. [PubMed: 18230063] 
97. Carmosino MJ, Friesen RH, Doran A, Ivy DD. Perioperative complications in children with pulmonary hypertension undergoing noncardiac surgery or cardiac catheterization. Anesth Analg. 2007; 104:521-527. [PubMed: 17312201]

98. Berman Rosenzweig E, Barst RJ. Pulmonary arterial hypertension : a comprehensive review of pharmacological treatment. Treat Respir Med. 2006; 5:117-127. [PubMed: 16512692]

99. Beghetti M. Current treatment options in children with pulmonary arterial hypertension and experiences with oral bosentan. European journal of clinical investigation. 2006; 36(Suppl 3):1624. [PubMed: 16919006]

100. Douwes JM, van Loon RL, Hoendermis ES, et al. Acute pulmonary vasodilator response in paediatric and adult pulmonary arterial hypertension: occurrence and prognostic value when comparing three response criteria. Eur Heart J. 2011

101. Sitbon O, Humbert M, Jais X, et al. Long-term response to calcium channel blockers in idiopathic pulmonary arterial hypertension. Circulation. 2005; 111:3105-3111. [PubMed: 15939821]

102. Barst RJ, McGoon MD, Elliott CG, Foreman AJ, Miller DP, Ivy DD. Survival in childhood pulmonary arterial hypertension: insights from the registry to evaluate early and long-term pulmonary arterial hypertension disease management. Circulation. 2012; 125:113-122. [PubMed: 22086881]

103. Yung D, Widlitz AC, Rosenzweig EB, Kerstein D, Maislin G, Barst RJ. Outcomes in children with idiopathic pulmonary arterial hypertension. Circulation. 2004; 110:660-665. [PubMed: 15289375]

104. Christman BW, McPherson CD, Newman JH, et al. An imbalance between the excretion of thromboxane and prostacyclin metabolites in pulmonary hypertension. New England Journal of Medicine. 1992; 327:70-75. [PubMed: 1603138]

105. Adatia I, Barrow SE, Stratton PD, Miall-Allen VM, Ritter JM, Haworth SG. Thromboxane A2 and prostacyclin biosynthesis in children and adolescents with pulmonary vascular disease. Circulation. 1993; 88:2117-2122. [PubMed: 8222105]

106. Tuder RM, Cool CD, Geraci MW, et al. Prostacyclin synthase expression is decreased in lungs from patients with severe pulmonary hypertension. Am J Respir Crit Care Med. 1999; 159:19251932. [PubMed: 10351941]

107. Siehr SL, Ivy DD, Miller-Reed K, Ogawa M, Rosenthal DN, Feinstein JA. Children with pulmonary arterial hypertension and prostanoid therapy: long-term hemodynamics. J Heart Lung Transplant. 2013; 32:546-552. [PubMed: 23453572]

108. Lammers AE, Hislop AA, Flynn Y, Haworth SG. Epoprostenol treatment in children with severe pulmonary hypertension. Heart. 2007; 93:739-743. [PubMed: 17065181]

109. Ivy DD, Doran A, Claussen L, Bingaman D, Yetman A. Weaning and discontinuation of epoprostenol in children with idiopathic pulmonary arterial hypertension receiving concomitant bosentan. Am J Cardiol. 2004; 93:943-946. [PubMed: 15050507]

110. Barst RJ, Galie N, Naeije R, et al. Long-term outcome in pulmonary arterial hypertension patients treated with subcutaneous treprostinil. Eur Respir J. 2006; 28:1195-1203. [PubMed: 16899485]

111. Gomberg-Maitland M, Tapson VF, Benza RL, et al. Transition from intravenous epoprostenol to intravenous treprostinil in pulmonary hypertension. Am J Respir Crit Care Med. 2005; 172:1586-1589. [PubMed: 16151039]

112. Ivy DD, Claussen L, Doran A. Transition of stable pediatric patients with pulmonary arterial hypertension from intravenous epoprostenol to intravenous treprostinil. Am J Cardiol. 2007; 99:696-698. [PubMed: 17317374]

113. Bloodstream infections among patients treated with intravenous epoprostenol or intravenous treprostinil for pulmonary arterial hypertension--seven sites, United States, 2003-2006. MMWR Morb Mortal Wkly Rep. 2007; 56:170-172. [PubMed: 17332729]

114. Doran AK, Ivy DD, Barst RJ, Hill N, Murali S, Benza RL. Guidelines for the prevention of central venous catheter-related blood stream infections with prostanoid therapy for pulmonary arterial hypertension. Int J Clin Pract Suppl. 2008:5-9. [PubMed: 18638170]

115. Ferdman DJ, Rosenzweig EB, Zuckerman WA, Krishnan U. Subcutaneous treprostinil for pulmonary hypertension in chronic lung disease of infancy. Pediatrics. 2014; 134:e274-e278. [PubMed: 24982101] 
116. Levy M, Celermajer DS, Bourges-Petit E, Del Cerro MJ, Bajolle F, Bonnet D. Add-on therapy with subcutaneous treprostinil for refractory pediatric pulmonary hypertension. The Journal of pediatrics. 2011; 158:584-588. [PubMed: 21035821]

117. Takatsuki S, Parker DK, Doran AK, Friesen RH, Ivy DD. Acute pulmonary vasodilator testing with inhaled treprostinil in children with pulmonary arterial hypertension. Pediatr Cardiol. 2013; 34:1006-1012. [PubMed: 23184020]

118. Krishnan U, Takatsuki S, Ivy DD, et al. Effectiveness and safety of inhaled treprostinil for the treatment of pulmonary arterial hypertension in children. Am J Cardiol. 2012; 110:1704-1709. [PubMed: 22917554]

119. Voswinckel R, Enke B, Reichenberger F, et al. Favorable effects of inhaled treprostinil in severe pulmonary hypertension: results from randomized controlled pilot studies. Journal of the American College of Cardiology. 2006; 48:1672-1681. [PubMed: 17045906]

120. Jing ZC, Parikh K, Pulido T, et al. Efficacy and safety of oral treprostinil monotherapy for the treatment of pulmonary arterial hypertension: a randomized, controlled trial. Circulation. 2013; 127:624-633. [PubMed: 23307827]

121. Tapson VF, Jing ZC, Xu KF, et al. Oral treprostinil for the treatment of pulmonary arterial hypertension in patients receiving background endothelin receptor antagonist and phosphodiesterase type 5 inhibitor therapy (the FREEDOM-C2 study): a randomized controlled trial. Chest. 2013; 144:952-958. [PubMed: 23669822]

122. Olschewski H, Simonneau G, Galie N, et al. Inhaled iloprost for severe pulmonary hypertension. N Engl J Med. 2002; 347:322-329. [PubMed: 12151469]

123. Ivy DD, Doran AK, Smith KJ, et al. Short- and long-term effects of inhaled iloprost therapy in children with pulmonary arterial hypertension. J Am Coll Cardiol. 2008; 51:161-169. [PubMed: 18191742]

124. Limsuwan A, Wanitkul S, Khosithset A, Attanavanich S, Samankatiwat P. Aerosolized iloprost for postoperative pulmonary hypertensive crisis in children with congenital heart disease. Int J Cardiol. 2008; 129:333-338. [PubMed: 18096256]

125. Rubin LJ, Badesch DB, Barst RJ, et al. Bosentan therapy for pulmonary arterial hypertension. N Engl J Med. 2002; 346:896-903. [PubMed: 11907289]

126. Simonneau G, Rubin LJ, Galie N, et al. Addition of sildenafil to long-term intravenous epoprostenol therapy in patients with pulmonary arterial hypertension: a randomized trial. Ann Intern Med. 2008; 149:521-530. [PubMed: 18936500]

127. Taguchi M, Ichida F, Hirono K, et al. Pharmacokinetics of bosentan in routinely treated Japanese pediatric patients with pulmonary arterial hypertension. Drug Metab Pharmacokinet. 2011

128. Hislop AA, Moledina S, Foster H, Schulze-Neick I, Haworth SG. Long-term efficacy of bosentan in treatment of pulmonary arterial hypertension in children. Eur Respir J. 2011; 38:70-77. [PubMed: 21177841]

129. Beghetti M, Haworth SG, Bonnet D, et al. Pharmacokinetic and clinical profile of a novel formulation of bosentan in children with pulmonary arterial hypertension: the FUTURE-1 study. Br J Clin Pharmacol. 2009; 68:948-955. [PubMed: 20002090]

130. Beghetti M. Bosentan in pediatric patients with pulmonary arterial hypertension. Current vascular pharmacology. 2009; 7:225-233. [PubMed: 19356006]

131. Beghetti M, Hoeper MM, Kiely DG, et al. Safety experience with bosentan in 146 children 2-11 years old with pulmonary arterial hypertension: results from the European Postmarketing Surveillance program. Pediatr Res. 2008; 64:200-204. [PubMed: 18414142]

132. Maiya S, Hislop AA, Flynn Y, Haworth SG. Response to bosentan in children with pulmonary hypertension. Heart. 2006; 92:664-670. [PubMed: 16216850]

133. Rosenzweig EB, Ivy DD, Widlitz A, et al. Effects of long-term bosentan in children with pulmonary arterial hypertension. J Am Coll Cardiol. 2005; 46:697-704. [PubMed: 16098438]

134. Barst RJ, Ivy D, Dingemanse J, et al. Pharmacokinetics, safety, and efficacy of bosentan in pediatric patients with pulmonary arterial hypertension. Clin Pharmacol Ther. 2003; 73:372-382. [PubMed: 12709727]

135. Pulido T, Adzerikho I, Channick RN, et al. Macitentan and morbidity and mortality in pulmonary arterial hypertension. N Engl J Med. 2013; 369:809-818. [PubMed: 23984728] 
136. Galie N, Olschewski H, Oudiz RJ, et al. Ambrisentan for the treatment of pulmonary arterial hypertension: results of the ambrisentan in pulmonary arterial hypertension, randomized, doubleblind, placebo-controlled, multicenter, efficacy (ARIES) study 1 and 2. Circulation. 2008; 117:3010-3019. [PubMed: 18506008]

137. Takatsuki S, Rosenzweig EB, Zuckerman W, Brady D, Calderbank M, Ivy DD. Clinical safety, pharmacokinetics, and efficacy of ambrisentan therapy in children with pulmonary arterial hypertension. Pediatr Pulmonol. 2013; 48:27-34. [PubMed: 22511577]

138. Zuckerman WA, Leaderer D, Rowan CA, Mituniewicz JD, Rosenzweig EB. Ambrisentan for pulmonary arterial hypertension due to congenital heart disease. The American journal of cardiology. 2011; 107:1381-1385. [PubMed: 21371683]

139. Hanson KA, Ziegler JW, Rybalkin SD, Miller JW, Abman SH, Clarke WR. Chronic pulmonary hypertension increases fetal lung cGMP phosphodiesterase activity. Am J Physiol. 1998; 275:L931-L941. [PubMed: 9815111]

140. Humpl T, Reyes JT, Holtby H, Stephens D, Adatia I. Beneficial effect of oral sildenafil therapy on childhood pulmonary arterial hypertension: twelve-month clinical trial of a single-drug, openlabel, pilot study. Circulation. 2005; 111:3274-3280. [PubMed: 15956137]

141. Galie N, Ghofrani HA, Torbicki A, et al. Sildenafil citrate therapy for pulmonary arterial hypertension. N Engl J Med. 2005; 353:2148-2157. [PubMed: 16291984]

142. Takatsuki S, Calderbank M, Ivy DD. Initial experience with tadalafil in pediatric pulmonary arterial hypertension. Pediatr Cardiol. 2012; 33:683-688. [PubMed: 22402804]

143. Pettit RS, Johnson CE, Caruthers RL. Stability of an extemporaneously prepared tadalafil suspension. American journal of health-system pharmacy : AJHP : official journal of the American Society of Health-System Pharmacists. 2012; 69:592-594. [PubMed: 22441791]

144. Rosenzweig EB. Tadalafil for the treatment of pulmonary arterial hypertension. Expert Opin Pharmacother. 2010; 11:127-132. [PubMed: 20001434]

145. Galie N, Brundage BH, Ghofrani HA, et al. Tadalafil therapy for pulmonary arterial hypertension. Circulation. 2009; 119:2894-2903. [PubMed: 19470885]

146. Schulze-Neick I, Hartenstein P, Li J, et al. Intravenous sildenafil is a potent pulmonary vasodilator in children with congenital heart disease. Circulation. 2003; 108(Suppl 1):II167-II173. [PubMed: 12970227]

147. Stocker C, Penny DJ, Brizard CP, Cochrane AD, Soto R, Shekerdemian LS. Intravenous sildenafil and inhaled nitric oxide: a randomised trial in infants after cardiac surgery. Intensive Care Med. 2003; 29:1996-2003. [PubMed: 14530859]

148. Atz AMWD. Sildenafil ameliorates effects of inhaled nitric oxide withdrawal. Anesthesiology. 1999; 91:307-310. [PubMed: 10422958]

149. Namachivayam P, Theilen U, Butt WW, Cooper SM, Penny DJ, Shekerdemian LS. Sildenafil prevents rebound pulmonary hypertension after withdrawal of nitric oxide in children. Am J Respir Crit Care Med. 2006; 174:1042-1047. [PubMed: 16917115]

150. Karatza AA, Bush A, Magee AG. Safety and efficacy of sildenafil therapy in children with pulmonary hypertension. Int J Cardiol. 2005; 100:267-273. [PubMed: 15823634]

151. Fasnacht MS, Tolsa JF, Beghetti M. The Swiss registry for pulmonary arterial hypertension: the paediatric experience. Swiss Med Wkly. 2007; 137:510-513. [PubMed: 17990138]

152. Mourani PM, Sontag MK, Ivy DD, Abman SH. Effects of long-term sildenafil treatment for pulmonary hypertension in infants with chronic lung disease. J Pediatr. 2009; 154:379-384. 84 e1-84e 2. [PubMed: 18950791]

153. Haworth SG. The management of pulmonary hypertension in children. Arch Dis Child. 2008; 93:620-625. [PubMed: 18381346]

154. Barst RJ, Ivy DD, Gaitan G, et al. A randomized, double-blind, placebo-controlled, dose-ranging study of oral sildenafil citrate in treatment-naive children with pulmonary arterial hypertension. Circulation. 2012; 125:324-334. [PubMed: 22128226]

155. Barst RJ, Beghetti M, Pulido T, et al. STARTS-2: long-term survival with oral Sildenafil monotherapy in treatment-naive pediatric pulmonary arterial hypertension. Circulation. 2014; 129:1914-1923. [PubMed: 24637559] 
156. Schermuly RT, Janssen W, Weissmann N, Stasch JP, Grimminger F, Ghofrani HA. Riociguat for the treatment of pulmonary hypertension. Expert Opin Investig Drugs. 2011; 20:567-576.

157. Ghofrani HA, Galie N, Grimminger F, et al. Riociguat for the treatment of pulmonary arterial hypertension. N Engl J Med. 2013; 369:330-340. [PubMed: 23883378]

158. Ghofrani HA, D'Armini AM, Grimminger F, et al. Riociguat for the treatment of chronic thromboembolic pulmonary hypertension. N Engl J Med. 2013; 369:319-329. [PubMed: 23883377]

159. Barst RJ. Role of atrial septostomy in the treatment of pulmonary vascular disease. Thorax. 2000; 55:95-96. [PubMed: 10639523]

160. Kerstein D, Levy PS, Hsu DT, Hordof AJ, Gersony WM, Barst RJ. Blade balloon atrial septostomy in patients with severe primary pulmonary hypertension. Circulation. 1995; 91:20282035. [PubMed: 7534664]

161. Nihill MROLM, Mullins CE. Effects of atrial septostomy in patients with terminal cor pulmonale due to pulmonary vascular disease. Cathet Cardiovasc Diagn. 1991; 24:166-172. [PubMed: 1722434]

162. Sandoval J, Gaspar J, Pulido T, et al. Graded balloon dilation atrial septostomy in severe primary pulmonary hypertension. A therapeutic alternative for patients nonresponsive to vasodilator treatment. J Am Coll Cardiol. 1998; 32:297-304. [PubMed: 9708453]

163. Baruteau AE, Serraf A, Levy M, et al. Potts shunt in children with idiopathic pulmonary arterial hypertension: long-term results. Ann Thorac Surg. 2012; 94:817-824. [PubMed: 22704329]

164. Labombarda F, Maragnes P, Dupont-Chauvet P, Serraf A. Potts Anastomosis for Children with Idiopathic Pulmonary Hypertension. Pediatr Cardiol. 2009

165. Blanc J, Vouhe P, Bonnet D. Potts shunt in patients with pulmonary hypertension. N Engl J Med. 2004; 350:623. [PubMed: 14762197]

166. Mallory GB, Spray TL. Paediatric lung transplantation. Eur Resp J. 2004; 24:839-845.

167. Toyoda Y, Thacker J, Santos R, et al. Long-term outcome of lung and heart-lung transplantation for idiopathic pulmonary arterial hypertension. Ann Thorac Surg. 2008; 86:1116-1122. [PubMed: 18805144]

168. Aurora P, Boucek MM, Christie J, et al. Registry of the International Society for Heart and Lung Transplantation: tenth official pediatric lung and heart/lung transplantation report--2007. J Heart Lung Transplant. 2007; 26:1223-1228. [PubMed: 18096472]

169. Kirkby S, Hayes D Jr. Pediatric lung transplantation: indications and outcomes. Journal of thoracic disease. 2014; 6:1024-1031. [PubMed: 25132969]

170. Khan MS, Heinle JS, Samayoa AX, et al. Is lung transplantation survival better in infants? Analysis of over 80 infants. J Heart Lung Transplant. 2013; 32:44-49. [PubMed: 23164533]

171. Benden C, Edwards LB, Kucheryavaya AY, et al. The Registry of the International Society for Heart and Lung Transplantation: Sixteenth Official Pediatric Lung and Heart-Lung Transplantation Report--2013; focus theme: age. J Heart Lung Transplant. 2013; 32:989-997. [PubMed: 24054807]

172. Mourani PM, Abman SH. Pulmonary vascular disease in bronchopulmonary dysplasia: pulmonary hypertension and beyond. Curr Opin Pediatr. 2013; 25(3):329-337. [PubMed: 23615175]

173. An HS, Bae EJ, Kim GB. Pulmonary hypertension in preterm infants with bronchopulmonary dysplasia. Korean Circ J. 2010; 40(3):131-136. [PubMed: 20339498]

174. Bhat R, Salas AA, Foster C. Prospective analysis of pulmonary hypertension in extremely low birth weight infants. Pediatrics. 2012; 129(3):e682-e689. [PubMed: 22311993] 


\section{Key Points}

- $\quad$ The prevalence of $\mathrm{PH}$ is increasing in the pediatric population, due to improved recognition and increased survival of patients, and remains a significant cause of morbidity and mortality.

- $\quad$ Recent studies have improved understanding of pediatric PH but management remains challenging due to lack of evidence based clinical trials.

- $\quad$ The growing contribution of developmental lung disease requires dedicated research to explore use of existing therapies as well as creation of novel therapies.

- $\quad$ Adequate study of pediatric PH will require multicenter collaboration due to the small numbers of patients, multifactorial disease etiologies and practice variability. 


\section{Box 1}

Developmental Lung Diseases Associated With Pulmonary Hypertension

\begin{tabular}{|l|}
\hline Congenital diaphragmatic hernia \\
\hline Bronchopulmonary dysplasia \\
\hline Alveolar capillary dysplasia (ACD) \\
\hline ACD with misalignment of veins \\
\hline Lung hypoplasia ("primary" or "secondary") \\
\hline Surfactant protein abnormalities \\
\hline Surfactant protein B (SPB) deficiency \\
\hline SPC deficiency \\
\hline ATP-binding cassette A3 mutation \\
\hline Thyroid transcription factor 1/Nkx2.1 homeobox mutation \\
\hline Pulmonary interstitial glycogenosis \\
\hline Pulmonary alveolar proteinosis \\
\hline Pulmonary lymphangiectasia \\
\hline
\end{tabular}

From Ivy DD, Abman SH, Barst RJ, et al. Pediatric pulmonary hypertension. J Am Coll Cardiol 2013;62(25 Suppl):D117-26; with permission. 
Box 2

\section{Select Guidelines From the American Heart Association and American Thoracic Society Task Force}

Diagnosis, Assessments, Monitoring

1. After a comprehensive initial evaluation, serial echocardiograms should be performed. More frequent echocardiograms are recommended in the setting of changes in therapy or clinical condition (Class I; Level of Evidence B).

2. Cardiac catheterization is recommended before initiation of PAHtargeted therapy (Class I; Level ofEvidence B). Exceptions may include critically ill patients requiring immediate initiation of empirical therapy (Class I; Level of Evidence B).

3. Cardiac catheterization should include acute vasoreactivity testing (AVT) unless there is a specific contraindication (Class I; Level of Evidence A).

4. Repeat cardiac catheterization is recommended within 3 to 12 months after initiation of therapy to evaluate response or with clinical worsening (Class I; Level of Evidence B).

5. Brain natriuretic peptide (BNP) or N-terminal (NT) proBNP should be measured at diagnosis and during follow-up to supplement clinical decision (Class I; Level of Evidence B).

6.

Recommendations for genetic testing of first-degree relatives of patients with monogenic forms of HPAH include the following:

a. Genetic testing is indicated for risk stratification (Class I; Level of Evidence B).

b. Members of families afflicted with HPAH who develop new cardiorespiratory symptoms should be evaluated immediately for PAH (Class I; Level of Evidence B).

Bronchopulmonary Dysplasia

1. Screening for PH by echocardiogram is recommended in infants with established BPD (Class I; Level of Evidence B).

2. Evaluation and treatment of lung disease, including assessments for hypoxemia, aspiration, structural airway disease, and the need for changes in respiratory support, are recommended in infants with BPD and PH before initiation of PAH-targeted therapy (Class I; Level of Evidence B).

3. Evaluation for long-term therapy for PH in infants with BPD should follow recommendations for all children with $\mathrm{PH}$ and include cardiac 
catheterization to diagnose disease severity and potential contributing factors such as LV diastolic dysfunction, anatomic shunts, pulmonary vein stenosis, and systemic collaterals (Class I; Level of Evidence B).

4.

PAH-targeted therapy can be useful for infants with BPD and PH on optimal treatment of underlying respiratory and cardiac disease (Class IIa; Level of Evidence C).

Pharmacotherapy

1.

Recommendations for calcium channel blockers (CCBs) include the following:

a. CCBs should be given only to those patients who are reactive as assessed by AVT and $>1$ year of age (Class I; Level of Evidence C).

b. CCBs are contraindicated in children who have not undergone or are nonresponsive to AVT and in patients with right-sided heart dysfunction owing to the potential for negative inotropic effects of CCB therapy (Class III; Level of Evidence C).

2.

Oral PAH-targeted therapy in children with lower- risk PAH is recommended and should include either a phosphodiesterase type 5 (PDE5) inhibitor or an endothelin (ET) receptor antagonist (ERA) (Class I; Level of Evidence B).

3. Intravenous and subcutaneous prostacyclin or its analogs should be initiated without delay for patients with higher-risk PAH (Class I; Level of Evidence B).

4. Referral to lung transplantation centers for evaluation is recommended for patients who are in World Health Organization (WHO) functional class III or IV on optimized medical therapy or who have rapidly progressive disease (Class I; Level of Evidence A).

Outpatient Care of the Child with Pulmonary Hypertension

1. The following preventive care measures for health maintenance are recommended for pediatric patients with PH (Class I; Level of Evidence C):

a. Respiratory syncytial virus prophylaxis (if eligible)

b. Influenza and pneumococcal vaccinations

c. Rigorous monitoring of growth parameters

d. Prompt recognition and treatment of infectious respiratory illnesses 
e. Antibiotic prophylaxis for the prevention of sub-acute bacterial endocarditis in cyanotic patients and those with indwelling central lines

2. Because of the risks of syncope or sudden death with exertion, it is recommended that a thorough evaluation, including cardiopulmonary exercise testing (CPET) and treatment, be performed before the patient engages in athletic (symptom-limited) activities (Class I; Level of Evidence C).

3. Pediatric patients with severe PH (WHO functional class III or IV) or recent history of syncope should not participate in competitive sports (Class III;Level of Evidence C).

4. During exercise, it is recommended that pediatric patients with PH engage in light to moderate aerobic activity, avoid strenuous and isometric exertion, remain well hydrated, and be allowed to self-limit as required (Class I; Level of Evidence C). 
Box 3

\section{Updated Clinical Classification of Pulmonary Arterial Hypertension Associated}

A. Eisenmenger syndrome

Includes all large intra- and extra-cardiac defects which begin as systemic-to-pulmonary shunts and

progress with time to severe elevation of pulmonary vascular resistance (PVR) and to reversal (pulmonary-

to-systemic) or bidirectional shunting; cyanosis, secondary erythrocytosis and multiple organ involvement

are usually present.

B. Left-to-right shunts

$$
\begin{array}{ll}
\text { - } & \text { Correctable } \\
\text { - } & \text { Noncorrectable }
\end{array}
$$

Include moderate to large defects; PVR is mildly to moderately increased systemic-to-pulmonary shunting is still prevalent, whereas cyanosis is not a feature.

C. Pulmonary arterial hypertension $(\mathrm{PAH})$ with coincidental congenital heart disease

Marked elevation in PVR in the presence of small cardiac defects, which themselves do not account for the development of elevated PVR; the clinical picture is very similar to idiopathic PAH. To close the defects in

contraindicated.

D. Post-operative PAH

Congenital heart disease is repaired but PAH either persists immediately after surgery or recurs/develops months or years after surgery in the absence of significant postoperative hemodynamic lesions. The clinical phenotype is often aggressive.

\section{With Congenital Heart Disease}

From Simonneau G, Gatzoulis MA, Adatia I, et al. Updated clinical classification of pulmonary hypertension. J Am Coll Cardiol 2013;62(25 Suppl):D34-41; with permission. 
A)

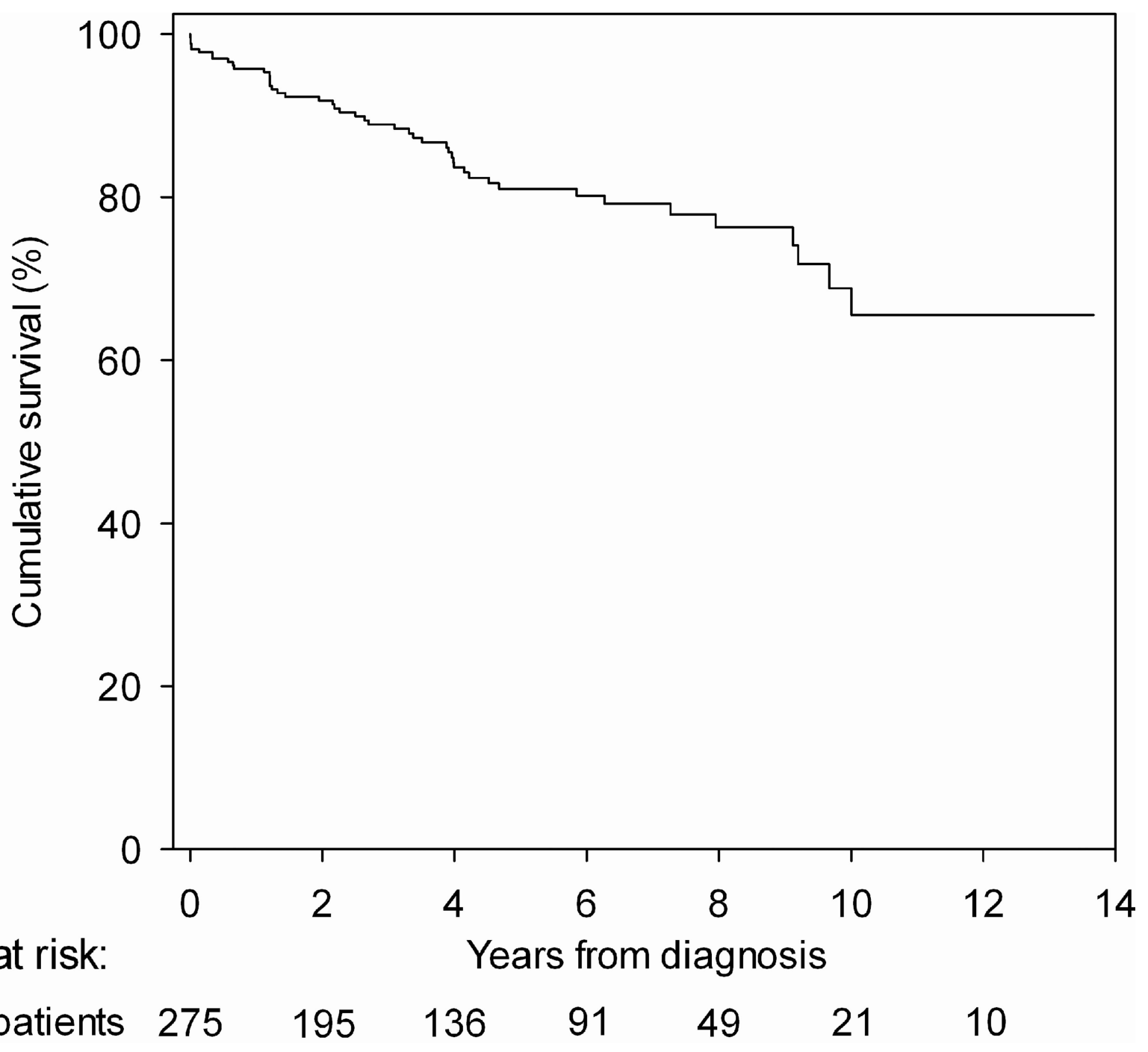

Patients at risk:

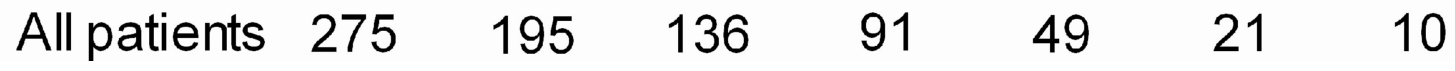

Figure 1.

Kaplan-Meier curves showing the survival pediatric PAH patients at $3 \mathrm{PH}$ centers (NY, New York; NL, Netherlands): 1-, 3-, 5-, and 7-year transplantation-free survival rates were 96\%, $89 \%, 81 \%$, and $79 \%$, respectively

From Zijlstra WM, Douwes JM, Rosenzweig EB. Survival differences in pediatric pulmonary arterial hypertension: clues to a better understanding of outcome and optimal treatment strategies. J Am Coll Cardiol 2014;63(20):2159-69; with permission. 


\section{Chromosomal or genetic syndromes}

\section{Pathological} insults on a growing lung

\section{Developmental abnormalities}

\section{Lung hypoplasia}

\section{Other \\ diseases and conditions}

Figure 2.

Venn diagram illustrating the heterogeneity and multifactorial elements in pediatric pulmonary hypertensive vascular disease.

Adapted from Cerro MJ, Abman S, Diaz G, et al. A consensus approach to the classification of pediatric pulmonary hypertensive vascular disease: Report from the PVRI Pediatric Taskforce, Panama 2011. Pulm Circ 2011;1(2):286-98; with permission. 


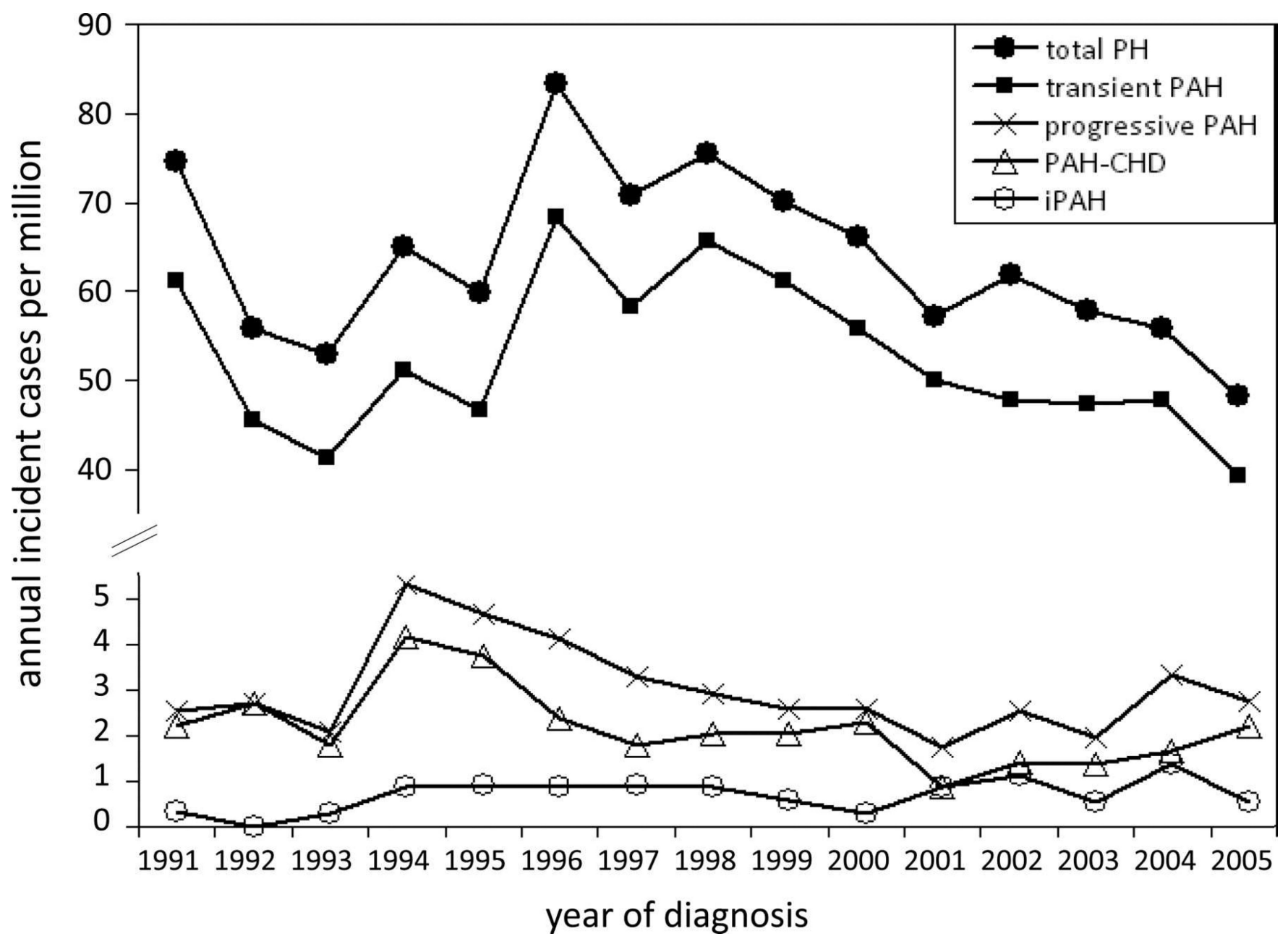

Figure 3.

Annual incidence rates for pediatric pulmonary hypertension. PH indicates pulmonary hypertension; PAH, pulmonary arterial hypertension; PAH-CHD, PAH associated with congenital heart defects; and IPAH, idiopathic PAH.

From van Loon RL, Roofthooft MT, Hillege HL, et al. Pediatric pulmonary hypertension in the Netherlands: epidemiology and characterization during the period 1991 to 2005. Circulation 2011;124(16):1755-64; with permission. 


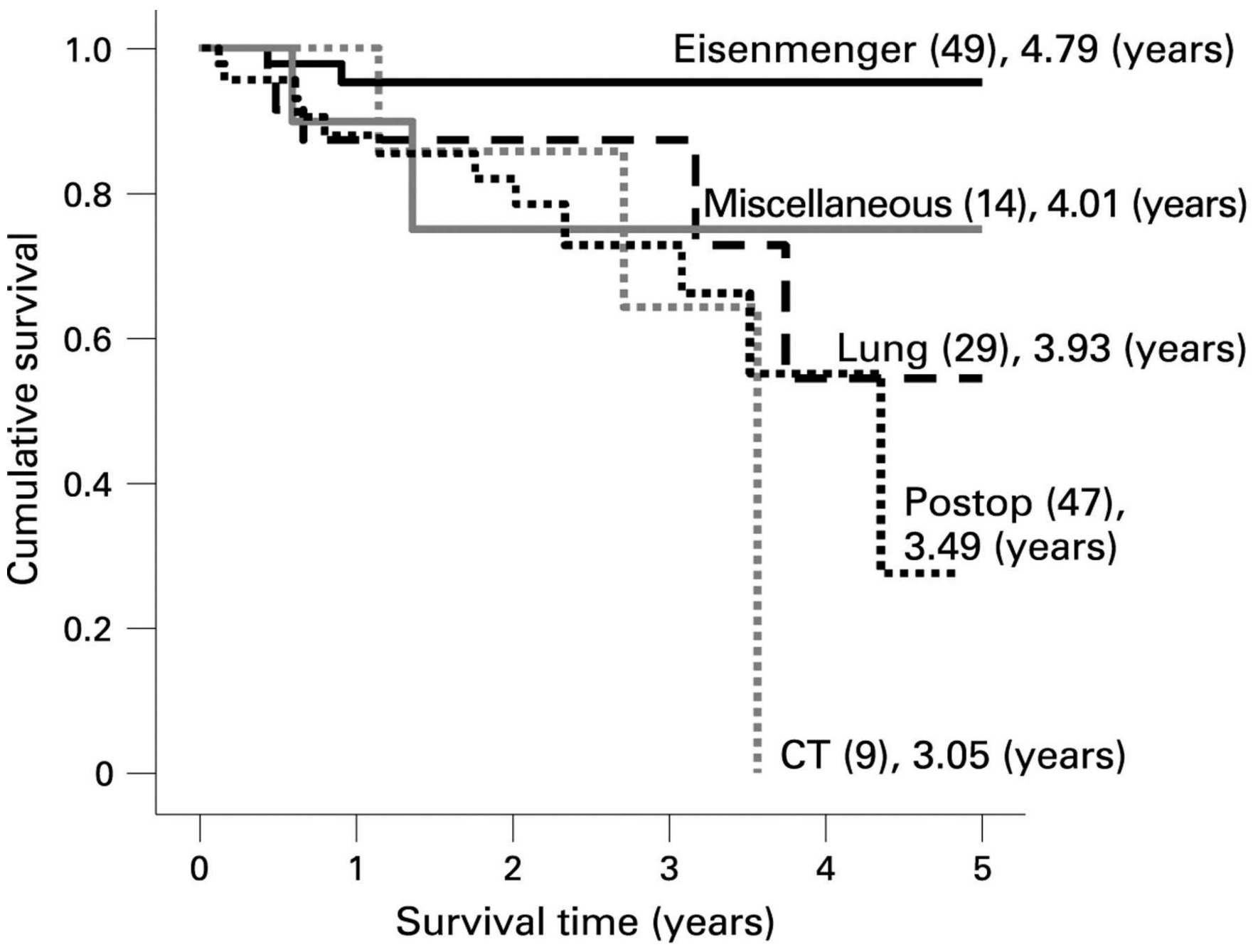

Figure 4.

Survival curves for the subgroups within the associated pulmonary arterial hypertension (APAH) group from the UK pulmonary hypertension service. The number in each group (brackets) and the predicted survival out of a possible 5 years is depicted. Note the worse survival for children with post operative congenital heart disease.

From Haworth SG, Hislop AA. Treatment and survival in children with pulmonary arterial hypertension: the UK Pulmonary Hypertension Service for Children 2001-2006. Heart 2009;95(4):312-7; with permission. 


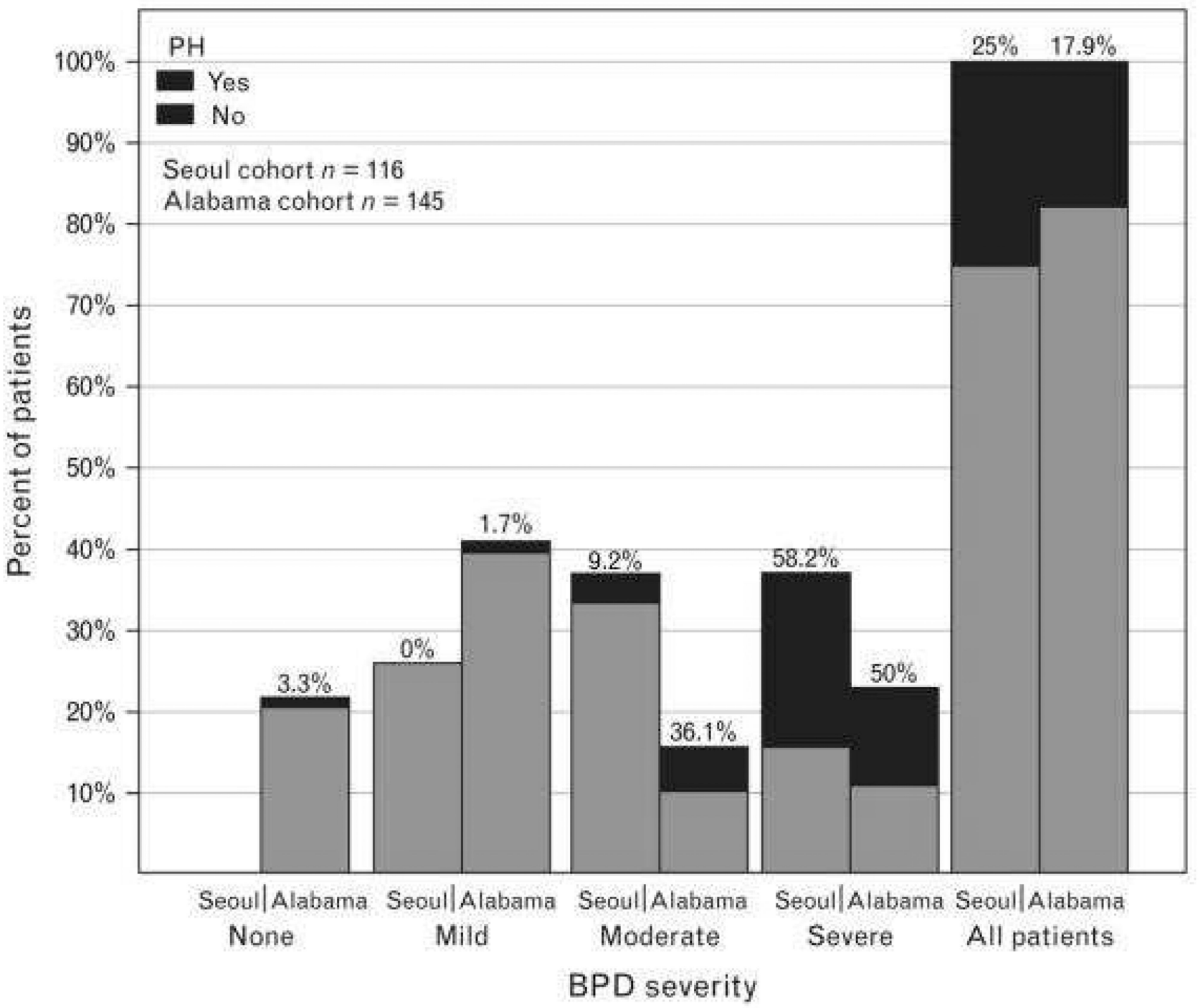

Figure 5.

The incidence of pulmonary hypertension according to the degree of bronchopulmonary dysplasia severity. Numbers above the bars indicate the percentage of patients with pulmonary hypertension.

Data from Refs ${ }^{172-174}$ 

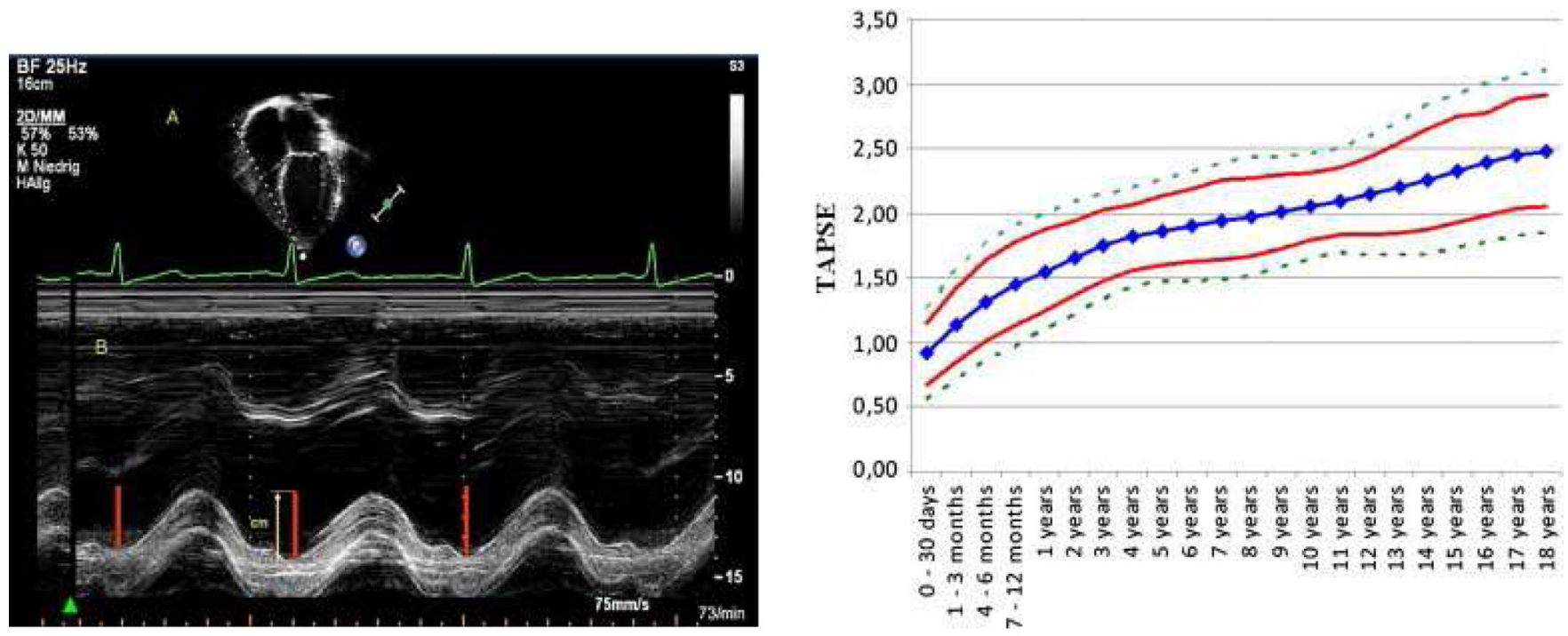

Age

Figure 6.

Measurement and normal values for tricuspid annular plane systolic excursion (TAPSE).

From Koestenberger M, Ravekes W, Everett AD. Right ventricular function in infants, children and adolescents: reference values of the tricuspid annular plane systolic excursion (TAPSE) in 640 healthy patients and calculation of z score values. J Am Soc Echocardiogr 2009;22(6):715-9; with permission. 

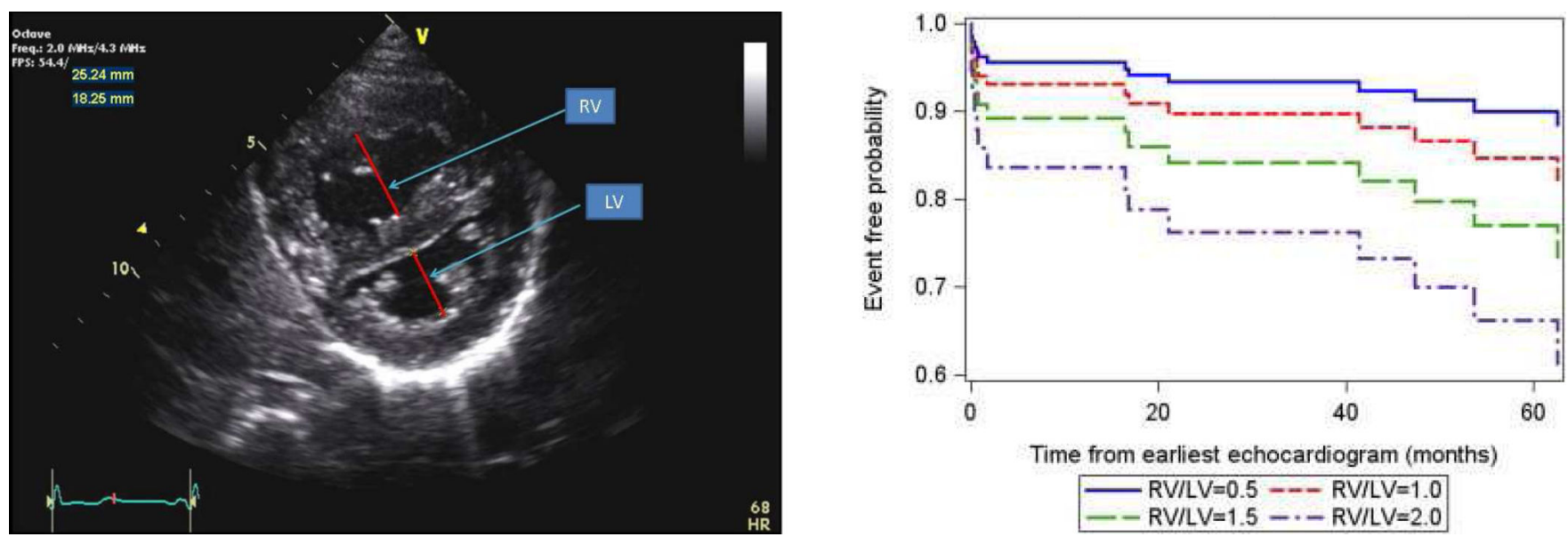

Figure 7.

Parasternal short axis view of the right and left ventricles at the level of the papillary muscles. The RV/LV ratio is derived from RV diameter and LV diameter at end-systole.

$\mathrm{RV} / \mathrm{LV}$ end systole ratio is predictive of outcome. Estimated survival curves for four possible $\mathrm{RV} / \mathrm{LV}$ ratios estimated from the Cox varying coefficients regression corresponding to a hazard ratio of 2.49 for $\mathrm{RV} / \mathrm{LV}$ ratio.

From Jone PN, Hinzman J, Wagner BD, et al. Right ventricular to left ventricular diameter ratio at end-systole in evaluating outcomes in children with pulmonary hypertension. J Am Soc Echocardiogr 2014;27(2):172-8; with permission. 

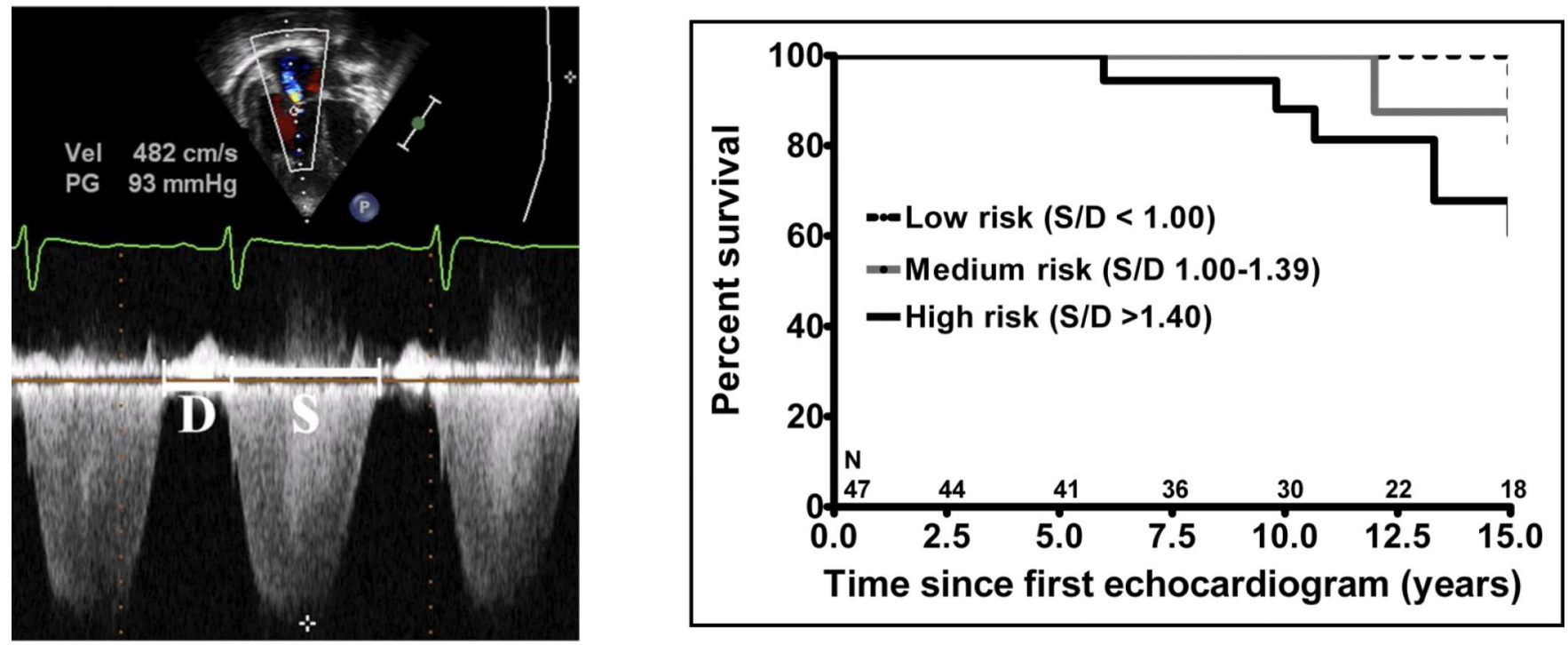

Figure 8.

The systolic $(\mathbf{S})$ to diastolic $(\mathbf{D})$ time ratio from tricuspid regurgitation velocity can be measured as a measure of right ventricular function. An increase in the S/D ratio predicts worse outcome in children with $\mathrm{PH}$.

Alkon et al in 2010 used an simple measure of systolic to diastolic time (S/D) ratio from the TR jet to evaluate pediatric $\mathrm{PH}$ patients and found that as the RV function worsens, the systolic portion of the cardiac cycle lengthens leading to an increased S:D ratio. S/D ratio was found to be higher in PH patients compared to controls and is associated with worse RV FAC change, worse hemodynamics by cath, shorter 6 minute walk test, and worse clinical outcomes independent of PVR or pressures. S/D ratio $<1$ is associated with low risk of negative outcome and S/D ratio $>1.4$ was associated with high risk of negative outcome. From Alkon J, Humpl T, Manlhiot C, et al. Usefulness of the right ventricular systolic to diastolic duration ration to predict functional capacity and survival in children with pulmonary arterial hypertension. Am J Cardiol 2010;106(3):430-6; with permission. 

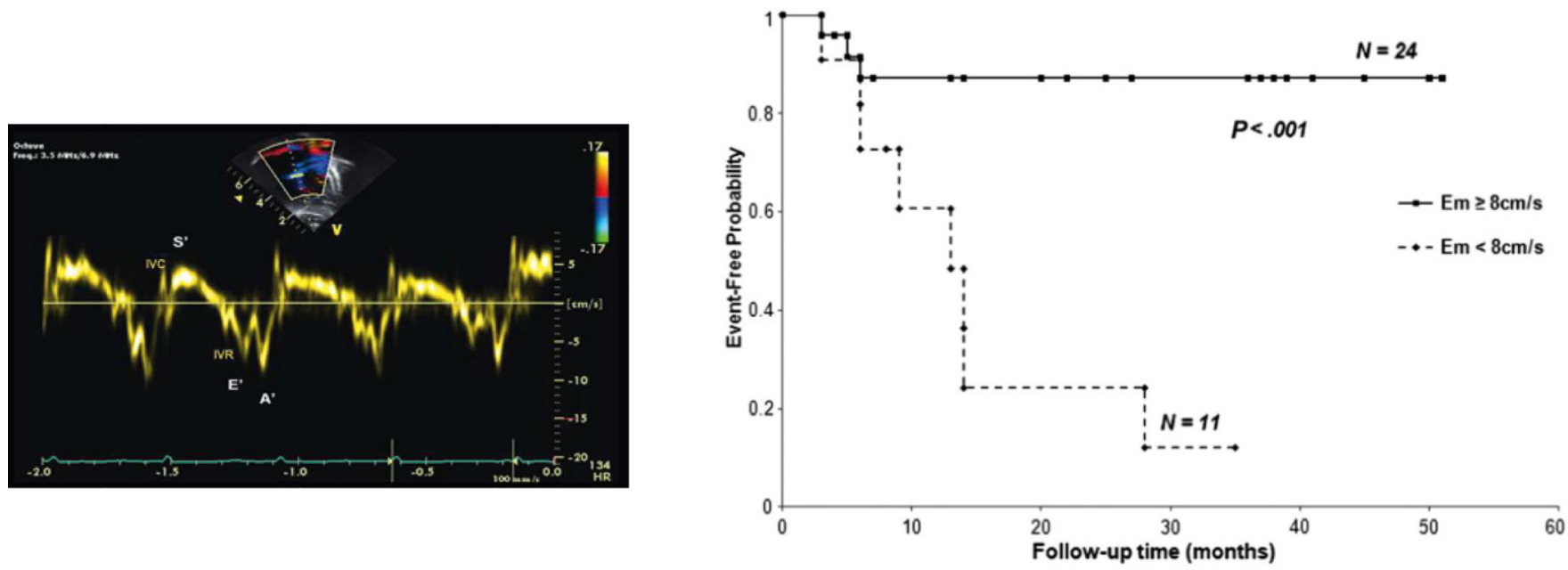

Figure 9.

Tissue Doppler imaging of the right ventricle at the lateral annulus of the tricuspid valve measures the myocardial systolic wave $\left(\mathbf{S}^{\prime}\right)$ which measures the systolic longitudinal function of the RV and two diastolic waves: early diastolic $\left(\mathbf{E}^{\prime}\right)$ and late diastolic $\left(\mathbf{A}^{\prime}\right)$, which denote the diastolic function of the ventricles. Low $\mathbf{E}^{\prime}$ velocity less than $8 \mathrm{~cm} / \mathrm{s}$ is predictive of poor outcome in pediatric IPAH.

From Takatsuki S, Nakayama T, Jone PN, et al. Tissue Doppler imaging predicts adverse outcome in children with idiopathic pulmonary arterial hypertension. J Pediatr 2012;161(6):

1126-31; with permission. 

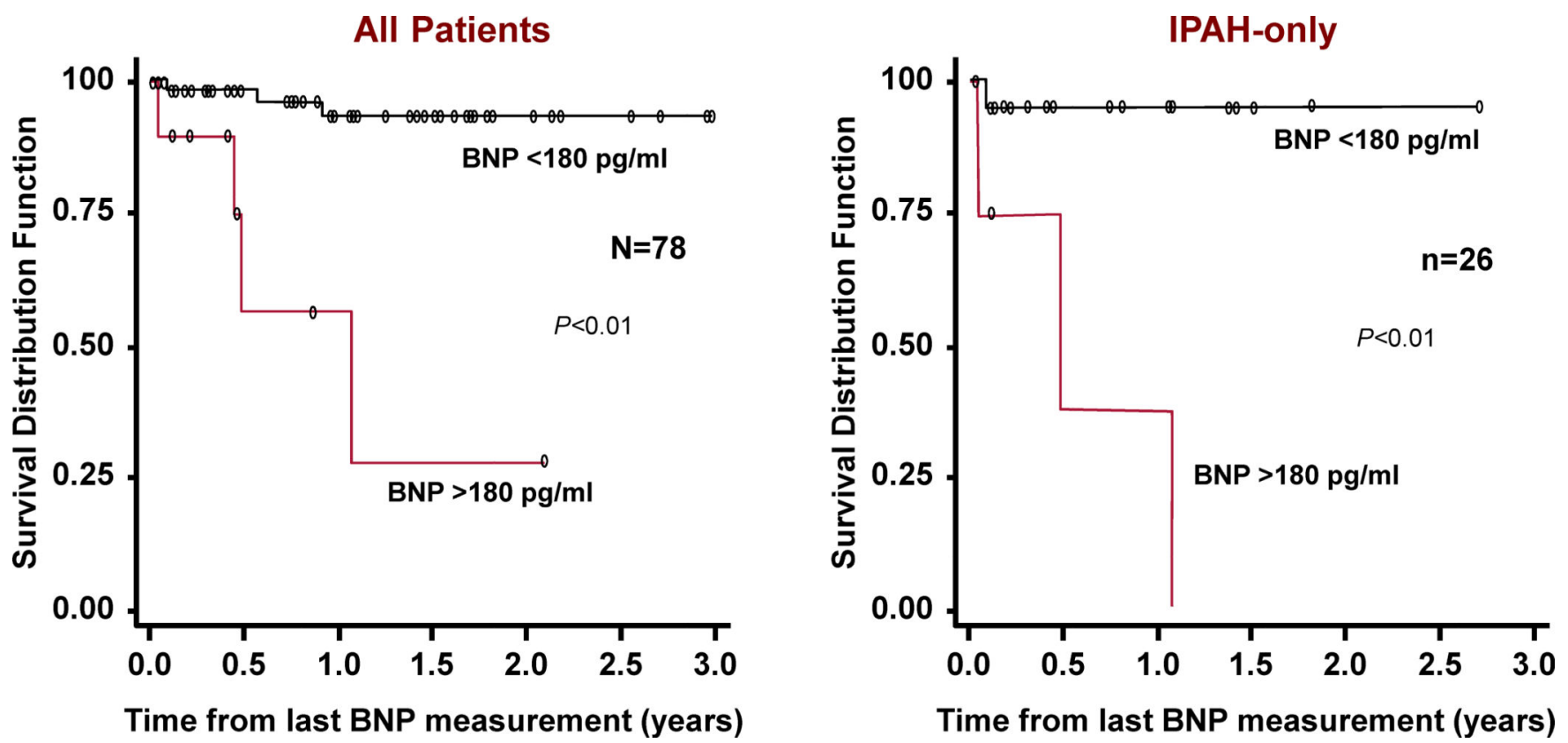

Figure 10.

Kaplan-Meier survival curves for children with IPAH and PAH associated with CHD.

Survival curves are shown for all patients (left) and for the subgroup of IPAH patients (right) categorized with either brain natriuretic peptide (BNP) $>180 \mathrm{pg} / \mathrm{ml}$ or $<180 \mathrm{pg} / \mathrm{ml}$.

From Bernus A, Wagner BD, Accurso F, et al. Brain natriuretic peptide levels in managing pediatric patients with pulmonary arterial hypertension. Chest 2009;135(3):745-51; with permission. 


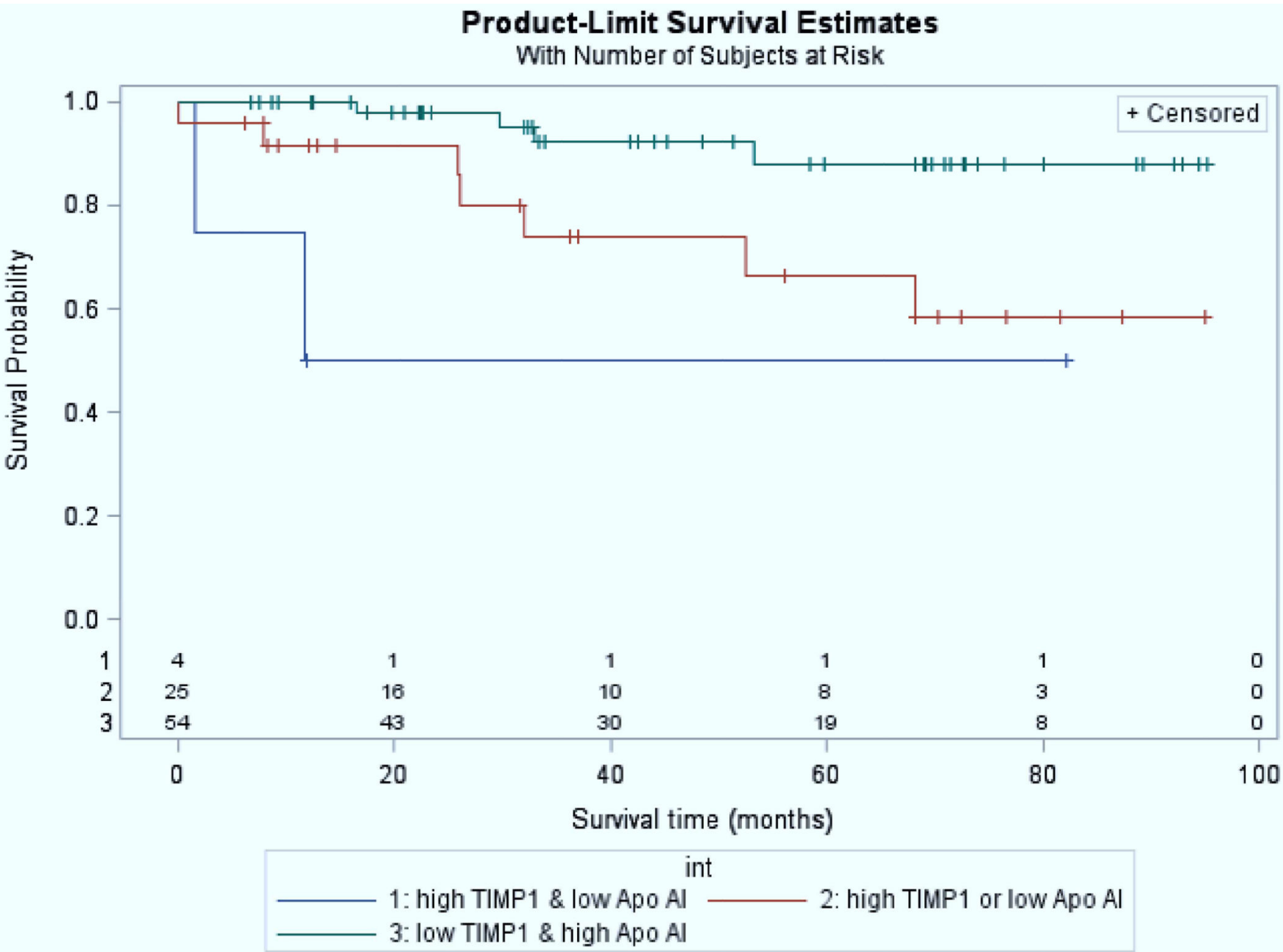

Figure 11.

High levels of tissue inhibitors of metalloproteinases-1 (TIMP-1), which is overexpressed by proinflammatory cytokines, and low levels of apolipoprotein-A1, which reduces levels of oxidized lipids and improves vascular disease are strongly associated with outcome in pediatric PH. Patients with high TIMP-1 and low apolipoprotein-AI values (red) had lower survival (log-rank test p-value, 0.01 ). The number of subjects at-risk are displayed along the $\mathrm{x}$-axis.

From Wagner BD, Takatsuki S, Accurso FJ, et al. Evaluation of circulating proteins and hemodynamics towards predicting mortality in children with pulmonary arterial hypertension. PLoS One 2013;8(11):e80235; with permission. 


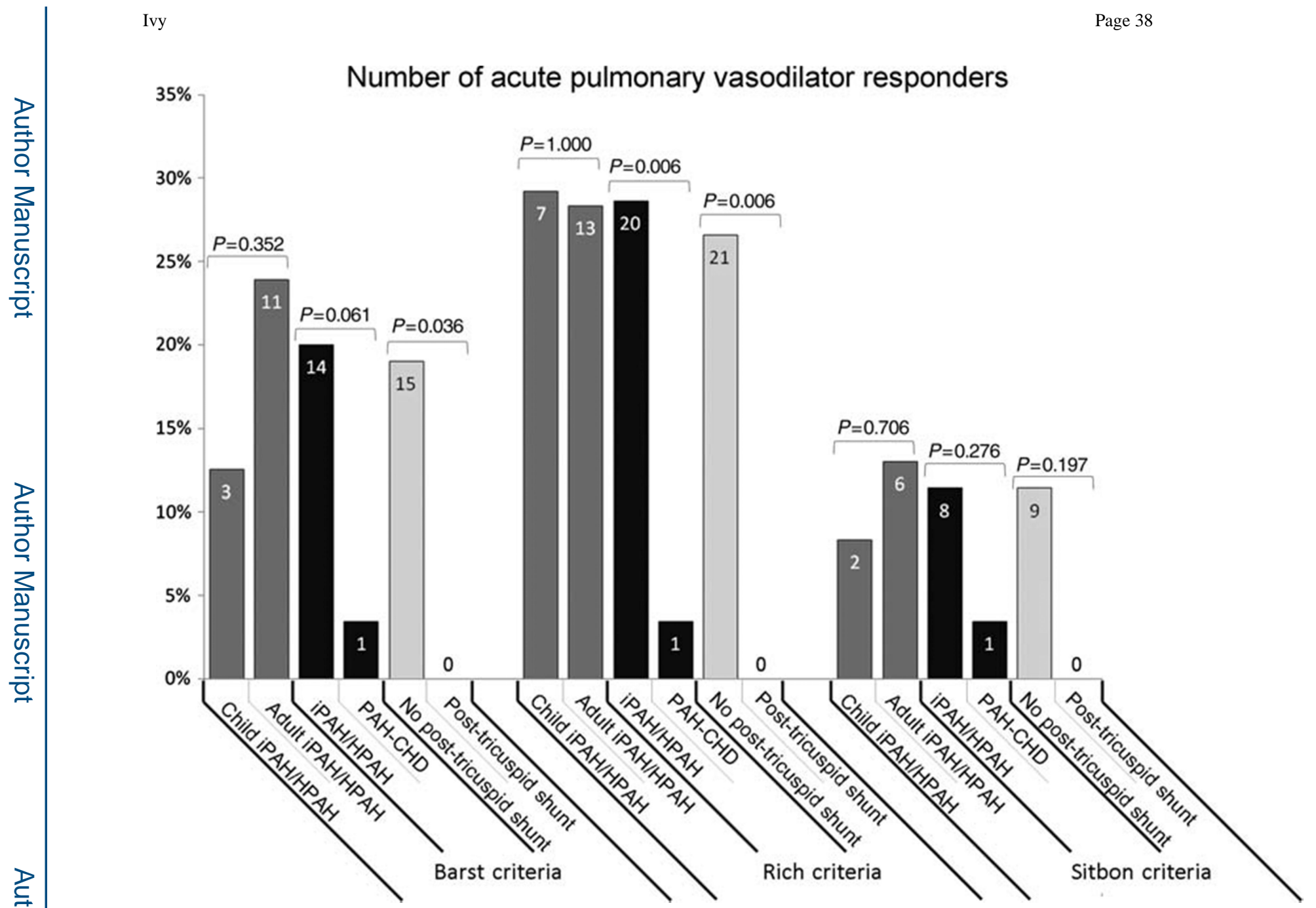

Fig 12.

The number of acute pulmonary vasodilator responders according to the three criteria in use, in children vs. adults with idiopathic pulmonary arterial hypertension (iPAH)/hereditary pulmonary arterial hypertension (HPAH), iPAH/HPAH vs. pulmonary arterial hypertension associated with congenital heart disease, and patients without vs. with post-tricuspid shunt, respectively. Data presented as percentage of patient group (\%) and patient numbers (indicated in bars). Comparison between groups performed using Fisher's exact test. Note the few $\%$ of patients with PAH-CHD responding to acute vasodilator challenge.

From Douwes JM, van Loon RL, Hoendermis ES, et al. Acute pulmonary vasodilator response in paediatric and adult pulmonary arterial hypertension: occurrence and prognostic value when comparing three response criteria. Eur Heart J 2011;32(24):3137-46; with permission. 


\begin{tabular}{|c|c|c|}
\hline LOWER RISK & DETERMINANTS OF RISK & HIGHER RISK \\
\hline No & Clinical evidence of RV failure & Yes \\
\hline No & Progression of Symptoms & Yes \\
\hline \multirow[t]{2}{*}{ No } & Syncope & Yes \\
\hline & Growth & Failure to thrive \\
\hline $\mathrm{I}, \mathrm{II}$ & WHO Functional Class & III,IV \\
\hline \multirow[t]{2}{*}{ Minimally elevated } & BNP / NTproBNP & $\begin{array}{c}\text { Significantly elevated } \\
\text { Rising level }\end{array}$ \\
\hline & Echocardiography & $\begin{array}{c}\text { Severe RV } \\
\text { enlargement/dysfunction } \\
\text { Pericardial Effusion }\end{array}$ \\
\hline $\begin{array}{c}\text { Systemic } \mathrm{Cl}>3.0 \mathrm{~L} / \mathrm{min} / \mathrm{m}^{2} \\
\mathrm{mPAP} / \mathrm{mSAP}<0.75 \\
\text { Acute Vasoreactivity }\end{array}$ & Hemodynamics & $\begin{array}{c}\text { Systemic } \mathrm{Cl}<2.5 \mathrm{~L} / \mathrm{min} / \mathrm{m}^{2} \\
\mathrm{mPAP} / \mathrm{mSAP}>0.75 \\
\text { RAP }>10 \mathrm{mmHg} \\
\text { PVRI }>20 \mathrm{WU}^{*} \mathrm{~m}^{2}\end{array}$ \\
\hline
\end{tabular}

Figure 13.

Risk factors that should be considered when planning therapeutic management options in pulmonary hypertension. CI, cardiac index; mPAp, mean pulmonary artery pressure; mSAp, mean systemic aortic pressure; NT-proBNP, N-terminal-pro-brain natriuretic peptide; PVRI, indexed pulmonary vascular resistance; RAP, right atrial pressure; RV, right ventricle; SBNP, serum brain natriuretic peptide.

From Ivy DD, Abman SH, Barst RJ, et al. Pediatric pulmonary hypertension. J Am Coll Cardiol 2013;62(25 Suppl):D117-26; with permission. 


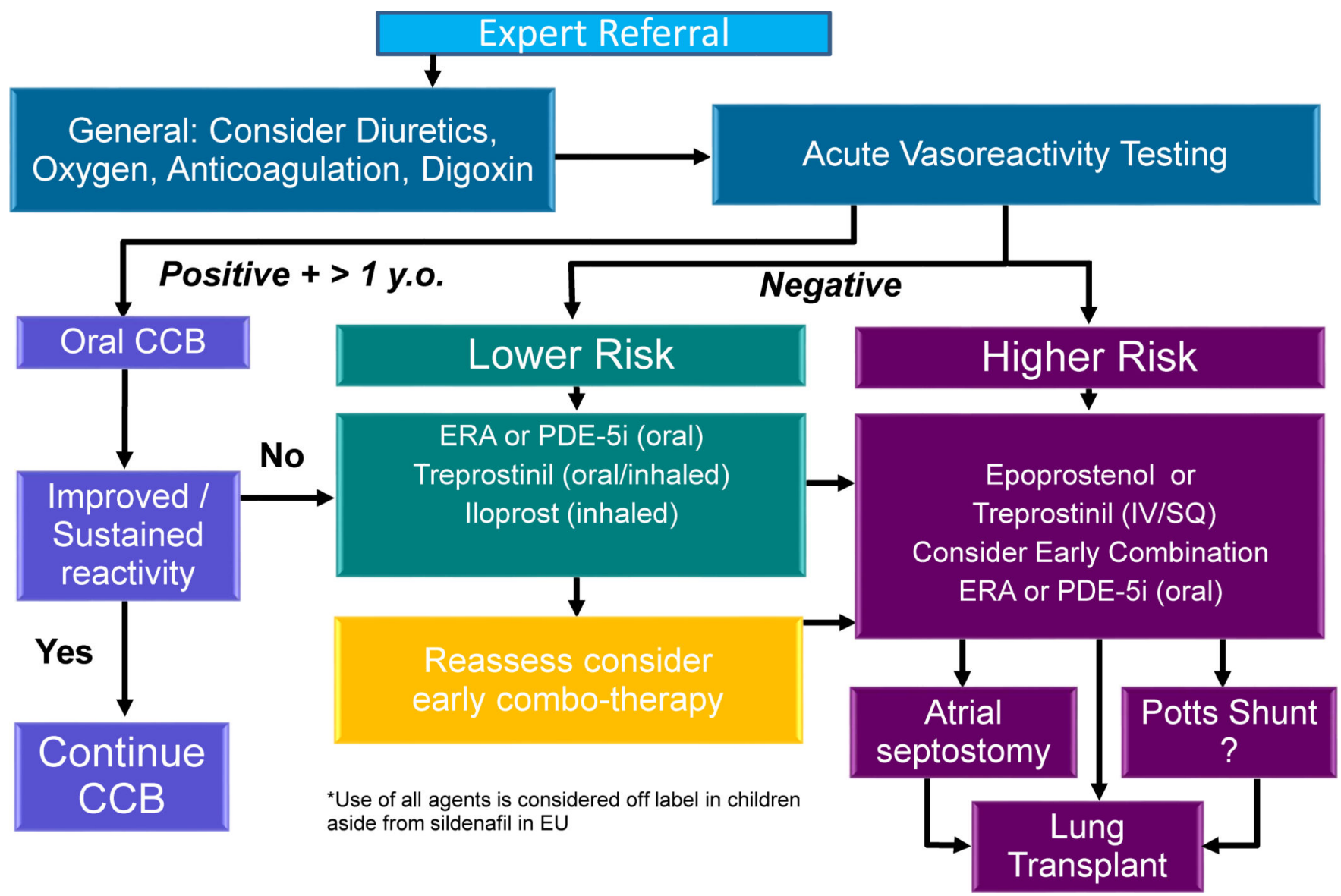

Figure 14.

Treatment algorithm proposed in the management of pediatric patients with idiopathic or heritable pulmonary arterial hypertension. This may be translatable to other patients with pulmonary hypertension. CCB, calcium channel blocker; ERA, endothelin receptor antagonist; PDE-5i, phosphodiesterase 5 inhibitor.

Adapted from Ivy DD, Abman SH, Barst RJ, et al. Pediatric pulmonary hypertension. J Am Coll Cardiol 2013;62(25 Suppl):D117-26; with permission. 
A

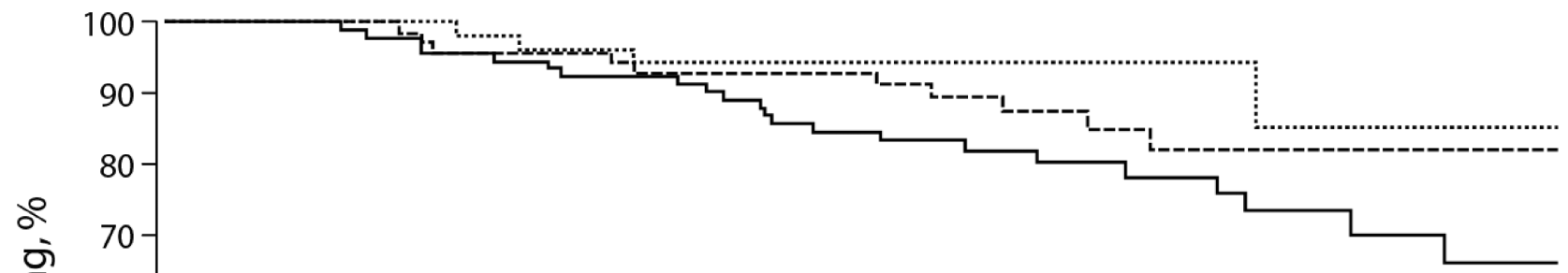

永

60

50

40

党 $30-$

$20-$....... Sildenafil Low Dose

$10-$----Sildenafil Medium Dose

$0-$

— Sildenafil High Dose

0

1

2

3

Patients at risk, $\mathrm{n}$

Low 55

Medium

74

54

73

100

96

52

68

48

66

86

79

4

6

Time, y

Figure 15.

Kaplan-Meier survival curve in 77 children with PH treated with epoprostenol, treprostinil, and those who transitioned, with 95\% confidence intervals (CI) depicted. Transplant-free 5year survival was 70\% (95\% CI, 56\%-80\%).

From Siehr SL, Ivy DD, Miller-Reed K, et al. Children with pulmonary arterial hypertension and prostanoid therapy: long-term hemodynamics. J Heart Lung Transplant 2013;32(5):54652; with permission. 


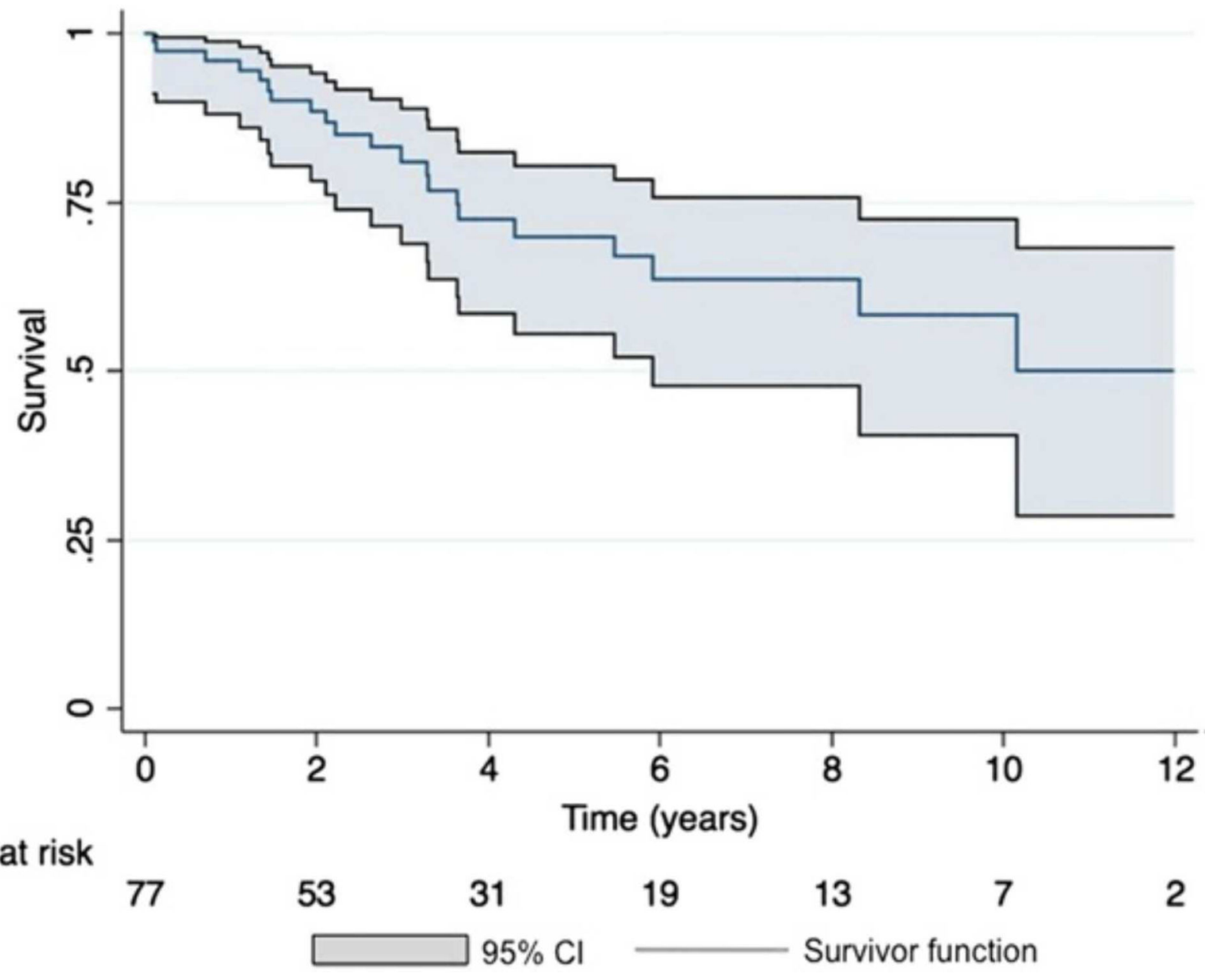

Figure 16.

Kaplan-Meier estimated survival from start of sildenafil treatment in Sildenafil in TreatmentNaive Children, Aged 1 to 17 Years, With Pulmonary Arterial Hypertension (STARTS-1) and STARTS-2. Patients were censored at the last date they were known to be alive; if a patient received a transplant, he or she was censored the day before transplant. Patients at risk are those who are ongoing in the study or known to be alive at the specified time (i.e., not dead, not lost to follow-up, or not in study long enough to reach time point).

From Barst RJ, Beghetti M, Pulido T, et al. STARTS-2: long-term survival with oral sildenafil monotherapy in treatment-naïve pediatric pulmonary arterial hypertension. Circulation 2014;129(19):1914-23; with permission. 


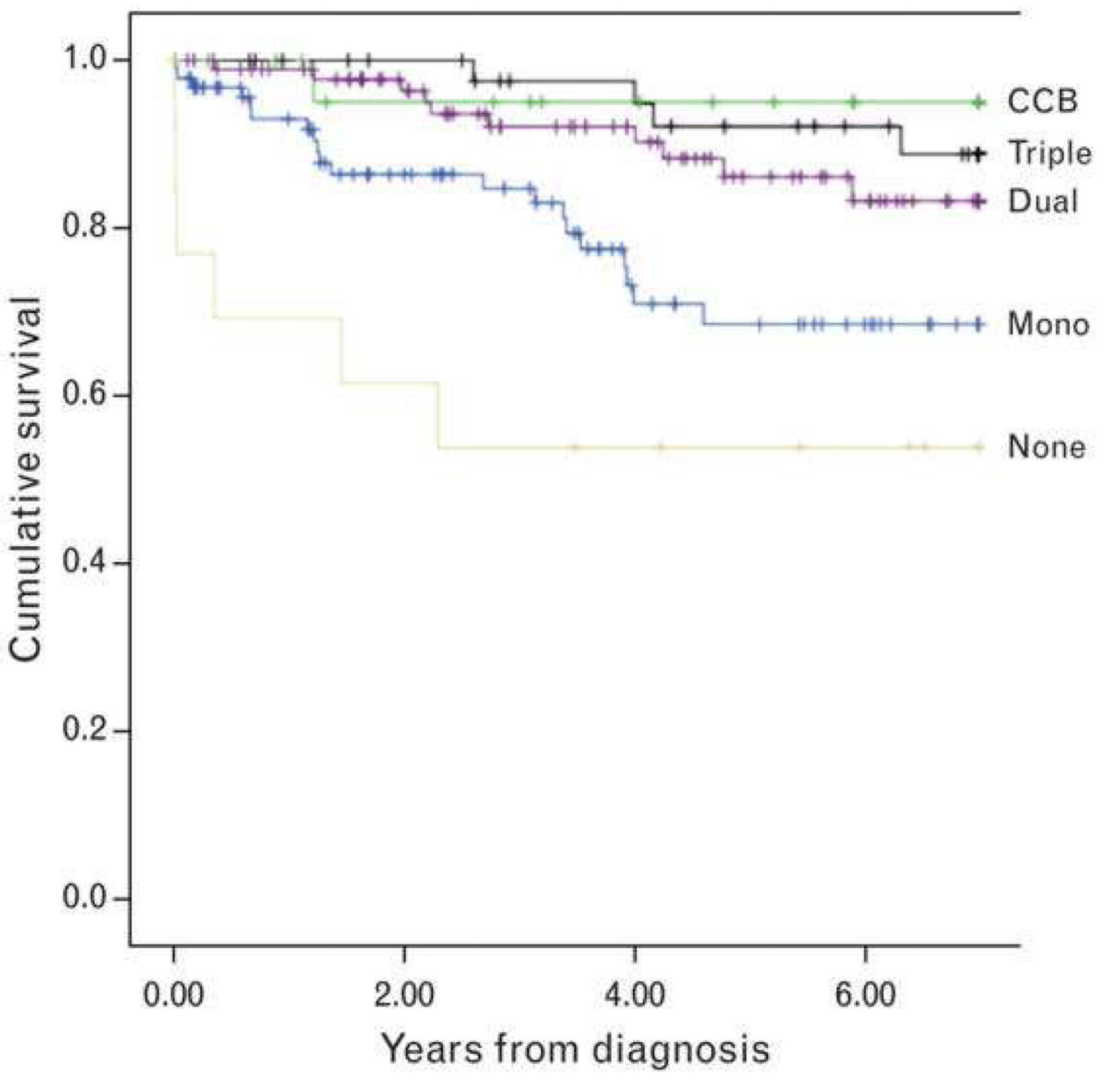

\section{Figure 17.}

Survival according to extent of pulmonary hypertension therapy in 275 recently diagnosed consecutive pediatric PAH patients at 3 referral centers between 2000 and 2010. Survival improves on combination therapy for pulmonary hypertension over monotherapy. CCB, calcium channel blocker.

From Zijlstra WM, Douwes JM, Rosenzweig EB. Survival differences in pediatric pulmonary arterial hypertension: clues to a better understanding of outcome and optimal treatment strategies. J Am Coll Cardiol 2014;63(20):2159-69; with permission. 


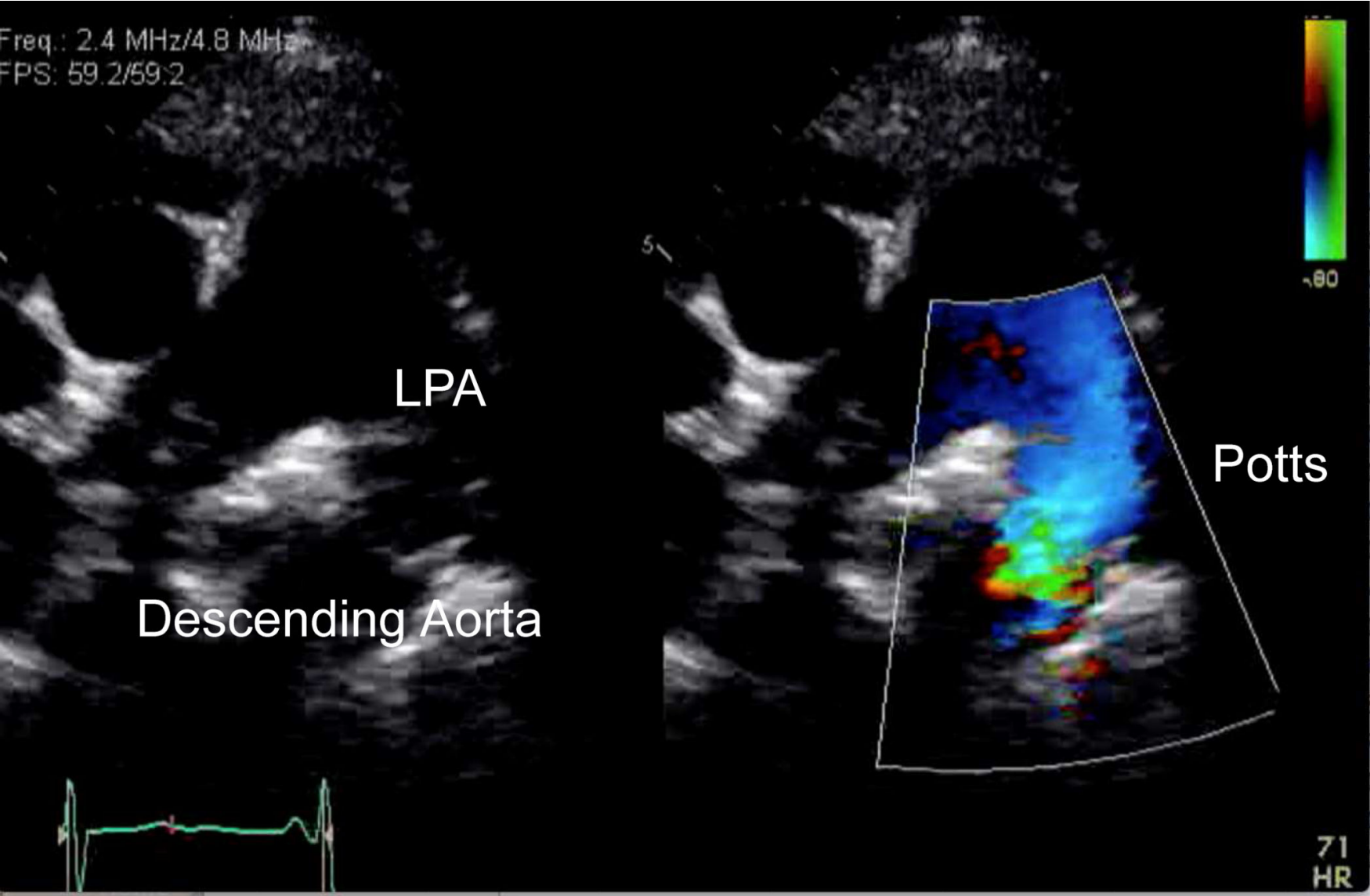

Figure 18.

Echocardiogram with color compare of the Potts shunt in a patient with severe IPAH. LPA, left pulmonary artery. 